\title{
The Mesozoic palaeorelief of the northern Tian Shan (China)
}

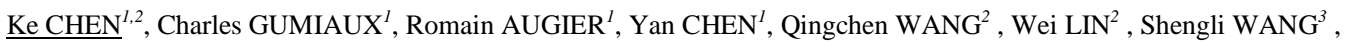 \\ 1. Institut des Sciences de la Terre d'Orléans (ISTO), Université d'Orléans, CNRS: UMR6113, Université François Rabelais - Tours, - INSU, \\ Campus Géosciences, 1A rue de la Férollerie, 45071 Orléans cedex 2, France
}

2. State Key Laboratory of Lithospheric Evolution, Institute of Geology and Geophysics, Chinese Academy of Sciences, P.O. 9825, Beijing 100029, China

3. Department of Earth Sciences, Nanjing University, 210093, Nanjing, China

\begin{abstract}
The Tian Shan range offers a natural laboratory to study orogenic processes. Most of the previous studies focused on either the Paleozoic evolution of the range or its Cenozoic intracontinental evolution linked with the India-Asia collision. In this study, detailed field investigations on the relationship between sedimentary cover and basement constrain the Mesozoic evolution of the northern Tian Shan. Sedimentological observations argue for limited transport distance for Lower and Uppermost Jurassic deposits. Geological sections presented in this paper show that, in preserved locations, Triassic to Jurassic sedimentary series present a continuous onlap type sedimentary unconformity on the top of the basement. At different scales, observations clearly evidence the existence of a major palaeorelief during Mesozoic. According to the present study, the current Tian Shan range topography and the associated movements along its northern front structures cannot be considered as the consequence of Cenozoic reactivation alone.
\end{abstract}

\section{Keywords}

Tian Shan, palaeorelief, Mesozoic, regional onlap, reactivation, India-Asia collision. 


\section{Introduction}

The modern Tian Shan is one of the major mountain ranges in Central Asia. The current structure of Tian Shan mainly results from a combination of two main tectonic events: i) subductions, arc-accretions and continental collision during Paleozoic (e.g. Carroll et al., 1990; Wang et al., 1990; Windley et al., 1990; Sengör et al. 1993; Carroll et al., 1995; Gao et al., 1998; Laurent-Charvet et al., 2002; Charvet et al., 2007; Wang et al., 2007) and ii) intracontinental reactivation linked to the India-Asia collision, during Cenozoic (e.g. Tapponnier and Molnar, 1977; Avouac et al., 1993). At first order, the modern Tian Shan corresponds to a raised east-west trending Paleozoic 'basement' range, flanked by two closed intracontinental basins whose infill is a particularly accurate record for both tectonic and climate evolutions (Fig. 1). The present-day high topography of Tian Shan, with a mean altitude of $\sim 2500 \mathrm{~m}$ and summits of more than $7000 \mathrm{~m}$, is traditionally related to the latest intracontinental deformation of the range (e.g. Tapponnier and Molnar, 1977; Avouac et al., 1993; Burchfiel et al., 1999). Age constraints for the onset of this intracontinental reactivation range from 10 to $24 \mathrm{Ma}$ (e.g. Avouac et al., 1993; Hendrix et al., 1994; Abdrakhmatov et al., 1996; Métivier and Gaudemer, 1997; Sobel et al., 1997; Dumitru et al., 2001; Charreau et al., 2009). In spite of relative age discrepancies (mostly related to the method applied), all ages estimated for the deformation and the associated relief erosion suggest that the mountain range reactivation and relief creation began during Early Miocene at oldest.

However, recent Fission-track analyses suggest that uplifting may have existed well before the onset of the Tertiary reactivation through Tian Shan, with exhumation ages such as 160-120 Ma in central Tian Shan, 200-250 Ma detritus cooling age in the Manas River valley (Dumitru et al., 2001; Jolivet et al., 2010) or 140-120 Ma from Bayanbulak intracontinental basin, in the southern Tian Shan (Wang et al., 2009). Moreover, Triassic to Cretaceous sediments are composed of thick continental series characterized by massive coarse-grained 
formations within both basins, suggesting rather high erosion rate at that time (Hendrix, 2000; Carroll et al., 2010).

This study considers the Mesozoic tectonic and morphologic evolution of Tian Shan through field structural and sedimentological analyses of Mesozoic deposits. It focuses on the northern piedmont of the range, along a $\sim 280 \mathrm{~km}$ west-east trending segment (Fig. 1). Thanks to deep incisions of seasonal rivers, contacts between Paleozoic basement and MesozoicCenozoic sedimentary cover are particularly well exposed along several north-south trending sections in this region (Fig. 1). Such new constraints on Mesozoic evolution of the Tian Shan area would lead to reconsider the contribution of Cenozoic tectonics in the modern mountain range building as well as to better quantify the net shortening amount during that period.

\section{Stratigraphy of the Mesozoic sediments within the study area}

Sedimentary series can be extensively observed and have already been studied within the Junggar basin, as summarized below (Figs. 1 and 2; Hendrix et al., 1992 and references therein; XBGMR, 1993). Basement units of the north Tian Shan mainly consist of Paleozoic volcanic and sedimentary rocks. From bottom to top, the entire Mesozoic series is composed of $\sim 5 \mathrm{~km}$ thick continental clastic deposits highlighting high sedimentation/preservation rates (Fig. 2). Thanks to numerous studies aimed at oil and gas exploration and to 1:200.000 mapping projects hold in this area, ages of the Mesozoic sequences were mainly constrained by floral and sporopollen assemblage analyses (Li et al., 1978; Yang et al., 1982; Liu, 1990; XBGMR, 1993; Lu and Deng, 2005; Yang et al., 2005; Huang and Li, 2007). In the study area, the Triassic series are mostly missing along the piedmont though locally exposed (Fig. 1). Where it crops out, Triassic displays alluvial sandstones and conglomerates intercalated within and silty mudstones (red-beds). At the scale of the northern Tian Shan piedmont, Lowermost Jurassic layers indicate a change in the sedimentation as they consist in thick and 
coarse conglomeratic deposits, as exposed in the south of Qingshui He (Fig. 3a). Thickness of Lower Jurassic reaches $1000 \mathrm{~m}$ over the area extending from Manasi to Urumqi, and decreases westwardly and eastwardly. Sediments become progressively finer upward, grading into $\sim 3 \mathrm{~km}$ thick series of Lower/Middle Jurassic gray sandstones, silty shales (Fig. 2). Middle Jurassic sandstones and mudstones locally contain coal-rich layers consistent with a lacustrine depositional facies (Hendrix et al., 1992). Upper Jurassic comprises typical finegrained red beds where conglomerates remain scarce. The transition from Jurassic to Cretaceous series is marked by up to $800 \mathrm{~m}$ thick sedimentary breccias (Kalaza formation J3k; Fig. 3b) made of coarse-grained angular clasts (Fig. 3c). It rapidly dies laterally and grades to sandstones within the Junggar basin itself (XBGMR, 1978; 1993). The marked unconformity between the Kalaza formation and the underlying finer-grained Upper Jurassic red beds (Fig. 3b) suggests a short transport distance of material before deposition and nearby relief uplifting.

In this study, Mesozoic sediments have also been extensively observed within internal parts of the range, and more particularly in the eastern part of the studied area (Fig. 1). Triassic to Jurassic sediments are encountered on top of the Paleozoic basement units, at rather high altitudes (2000 to $3000 \mathrm{~m}$ ) in comparison with the mean altitude of the foreland fold-and-thrust belts (1000 to $1500 \mathrm{~m}$ high). In the Houxia valley for instance - $65 \mathrm{~km} \mathrm{SSW}$ of Urumqi - a Lower to Upper Jurassic continuous sedimentary series is preserved in a syncline structure (Fig. 4a). According to the geological map (Fig. 4a; XBGMR, 1977), Lower Jurassic formations - i.e. Shangonghe Fm. to the northwest and Lowermost Jurassic Badaowan Fm. to the east - directly overlie on top of Carboniferous basement units, without intercalated Triassic sediments. Besides, south and north verging thrusts developed along parts of the northern and southern limbs of the fold, respectively (Fig. 4a). A section made across the north limb of the syncline displays continuous Lower to Middle Jurassic series with 
no fault contact observed (Fig. 4b). From south to north, bedding planes progressively straighten up from $\sim 30^{\circ}$ south dipping to vertical, and even overturned just below the south verging thrust (Figs. $4 \mathrm{a}, 4 \mathrm{~b}$ and $4 \mathrm{~d}$ ). From a sedimentological point of view, the upper and main part of Jurassic series is made of fine-grained sandstones and mudstones while the lowermost deposits of the series is characterized by intercalations of coarse-grained sedimentary breccias mostly made of highly angular clasts of Carboniferous tuffaceous sandstones (Fig. 4c). Local abundance of these breccias and the common lithological nature of the clasts with the adjacent basement unit strongly suggest a very short transport distance.

\section{Structural analysis of the Mesozoic basal contact}

Deformation of the northern Tian Shan has already been studied through the structural analysis of sedimentary series, within the Cenozoic foreland basin (e.g. Avouac et al., 1993; Deng et al., 1996; Burchfiel et al., 1999). This part focuses on the basal contact of the Mesozoic sediments, in the northern "front" area of Tian Shan.

As shown on the map (Fig. 1), some parts of the piedmont display northward thrusts that mark out the boundary in between the Paleozoic uplifted basement units and relatively subsiding proximal foreland basin. Yet, as described above, Mesozoic series are not solely restricted to the piedmont fold-and-thrust belts but are also well preserved on top of the basement units, within the range (Fig. 1). Then, some other segments of the piedmont display perfectly continuous Mesozoic sedimentary series from basin until internal and higher parts of the range, without being strained by any faulting or folding in the range front area (Fig. 1). Structural analysis of such unstrained basal contact of Mesozoic series is presented for two of the sections constructed from field work combined with available seismic profiles and drillholes data: the Hutubi He and the Wusu sections (Fig. 1). 
At first order, to the north of the Hutubi He area, Triassic to Neogene sedimentary series form a rather simple monocline structure, dipping $15-20^{\circ}$ to the north (Fig. 5a). The southernmost fold-and-thrust belt is composed of one gentle upright anticline and associated syncline with only very limited thrusts developed along the hinge of the fold (Fig. 5a). This belt can be regarded as a fault-propagation fold structure according to the available seismic profile (Wang et al., 2005; Fig. 5b). Further south, entering within the interior parts of the range, sub-horizontal Lower Jurassic strata lie on top of the Carboniferous units (Fig. 5b). While basement is strongly deformed, as evidenced by sub-vertical cleavage, its sedimentary cover is only gently folded as illustrated on the geological map, few kilometers west of the river (Fig. 5a; XBGMR, 1978, 1993). No décollement structure has been observed between the basement top and the sedimentary cover. Besides, a southward backthrust of basement rocks above sediments can be observed to the south of the section, but the net slip must be limited as it rapidly dies out, the fault laterally evolving to a fold toward the west (Fig. 5a). Unconformity of the basal contact of Mesozoic sediments on top of basement units is observed in the southernmost part of the section (Figs. 5a and 6a). As a whole, the successive sub-horizontal and monocline segments define a hinge fold at regional scale (Fig. 5b). Nevertheless, while $900 \mathrm{~m}$ thick of Triassic sediments have been drilled along the W1 well in the basin (Fig. 5b), no Triassic series have been observed further south in the range, in the section area (Fig. 5a). Indeed, Lowermost to Middle Jurassic levels have been observed and mapped directly on top of the basement units (Fig. 5a; XBGMR, 1978, 1993). Similarly to the Houxia area, basal contact of the Mesozoic series suggests its onlap deposit, from basin to range, at least during Triassic and Lower-Middle Jurassic.

More local-scale evidences for onlap sedimentation can also be observed in the Hutubi He area. First, to the south end of the section, Lower Jurassic strata display a kilometer scale onlap type structure on top of basement units, i.e. with younger sediments progressively 
covering basement, from north to south (Figs. 5a and 6a). Second, $10 \mathrm{~km}$ west of the Hutubi River, subhorizontal layers of the Lower Jurassic formation, which can be continuously followed in few kilometers in this small valley, structurally onlap on the deformed Paleozoic basement units (Fig. 6b). There, stratification planes are markedly oblique with the top of the Paleozoic units and no deformation has been observed along this contact. In the landscape, younger Jurassic sediments progressively extend to the south, on top of the Carboniferous units. Sediments progressively overlie and cover a $\sim 150 \mathrm{~m}$ high step of the basement top which implies that a significant relief existed during Jurassic sediments deposition.

To the north of the Wusu section, first-order structure of the Mesozoic-Cenozoic series displays a $40-45^{\circ}$ north dipping monocline (Figs. $7 \mathrm{a}$ and $7 \mathrm{~b}$ ). To the south, bedding is subhorizontal and structure of the sedimentary series is marked by a large hinge fold. As drawn on the geological map, thrust faults are observed at the surface, but seismic data show that they do not extend downward into the Mesozoic series (Fig. 7b; suppl. material), which is compatible with the limited throw produced by these faults as deduced from map data analysis (Fig. 7a). While $400 \mathrm{~m}$ of Triassic sediments have been found in a drilled well in the basin, close to this section (see W2 on Fig. 7a), Triassic series becomes much thinner to the south and Jurassic sandstones, sometimes, directly lie on top of the Carboniferous rocks with an erosional undeformed contact (Fig. 7c; XBGMR, 1973).

\section{Discussion and conclusions}

In parallel to rather classical view of frontal thrust systems, this study highlights that the northern piedmont of Tian Shan also displays segments where Mesozoic series are preserved unconformably onto the basement with onlap-type relationships. Such features are pointed out along two distant cross-sections and have also been clearly shown at outcrop-scale. Sedimentary breccias, showing very limited transport distances, have been found within 
Lower Jurassic sediments of the internal parts of the range. Whatever the scale, all these observations clearly show the existence of proximal relief when Triassic/Jurassic sediments were deposited. Our field observations are consistent with previously published sedimentological data - paleocurrent measurements, heavy mineral composition, sedimentological source analyses - in the Junggar and Tarim basins which suggest that Tian Shan could already have existed as a "positive" geomorphologic feature during Mesozoic times (Hendrix et al., 1992, Graham et al., 1993; Hendrix, 2000; Li et al., 2004).

In the field, the local-scale observation of onlap sedimentary architecture reveals that the paleo-altitude difference can reach $100-150 \mathrm{~m}$ in a hectometer horizontal distance, which highlights local steep slopes (cf. Fig. 6b). Together with the sedimentological observations in the Houxia valley, this suggests that small-scale ridges with intercalated intra-mountainous basins have probably existed during Mesozoic (Fig. 8a).

Drill wells W1 and W1' (Figs. 4a and 4b) display $\sim 1200 \mathrm{~m}$ of Lower Jurassic sediments (e.g. Badaowan and Shangonghe Fm., Fig. 2). A comparable thickness for Lower Jurassic has also been observed in the Manas area, $50 \mathrm{~km}$ west of the Hutubi section (Fig. 2; Hendrix et al., 1992). Following the geological maps (XBGMR; 1978, 1993), Middle Jurassic series directly lie unconformably onto the Carboniferous basement, without Triassic and Lower Jurassic sediments in the southern part of the Hutubi River (see location A in Fig. 4a). The thickness difference of Jurassic sediments reaches $\sim 1200 \mathrm{~m}$ between the location $\mathrm{A}$ and the drill well location, for a horizontal distance of about $50 \mathrm{~km}$ (Fig. 4a). Such thickness difference may result from subsidence mechanisms. However, whatever the scale considered in this study, Triassic and mostly Jurassic series, up to the late Jurassic Kalaza formation deposit, display parallel bedding with no growth strata observed (Figs. $5 b, 6$ and 7b). Such feature shows that, at the scale of the studied area, significant vertical differential movements may have hardly occurred during Triassic to Upper Jurassic sedimentation. In addition, as 
described above, Jurassic strata often overlie directly on Carboniferous by onlap, without fault or syn-sedimentary deformations. Seismic profiles across the southern margin of the Junggar basin do not display major fault that could have controlled sedimentation for the Early Jurassic period (Allen et al., 1991; Wang et al., 2005). No evidence for structural control on local subsidence could thus be argued here. At larger scale, flexure - either thermal or tectonic - could also have controlled the subsidence for Mesozoic series accumulation.

If considering thermal control, the latest regional tectono-magmatic event occurring before Mesozoic in the Central Tian Shan area ended during early Permian (see compilation by Han et al., 1999), which is about 100 Ma earlier than Jurassic sedimentation. Therefore, according to Hendrix et al. (1992), it seems that thermal driving mechanism may only play a weak role for the Early and Middle Jurassic sedimentation. If considering tectonic control, compressional flexure may also be hard to explain as, for comparable vertical differential movements, buckling of a stable continental lithosphere would result in much larger wavelength $(200-300 \mathrm{~km})$ than observed in this study $(\sim 50 \mathrm{~km})$ as shown by mechanical modelling (Martinod and Davy, 1992, 1994; Burov et al., 1993; Cloetingh et al., 1999).

At the scale of the present study, Jurassic sedimentation seems hardly controlled by either tectonic or thermal subsidence across northern Tian Shan. Accordingly, the 1200$1300 \mathrm{~m}$ thickness difference may be mainly produced by infilling of a long-lasting remnant relief of, at least, 1200-1300 m high at that period (i.e. from Triassic/Lowermost Jurassic; Fig. 8a). During Middle Jurassic, finer-grained sediments were conformably deposited on top of the Lower Jurassic strata within the basin, and were deposited onlap on the Paleozoic basement toward the range (Figs. 5a and 8b). Middle Jurassic sediments of the Xishanyao and Toutunhe formations extend to a larger area with respect to the Lower Jurassic and, as a whole, the paleorelief lateral extension was certainly less important during Middle Jurassic than during Triassic/Early Jurassic (Fig. 8b). During latest Jurassic to Early Cretaceous, thick 
breccias were deposited onto the Middle Jurassic sediments through an angular unconformity (cf. Kalaza Fm.). These breccias are restricted to the front of the modern Tian Shan and change rapidly to finer-grained deposits in lateral equivalents. This configuration is reminiscent of the general architecture of current fans deposited along the modern Tian Shan range that originate from the present day high relief to the south, but show limited northward transport of sediments (Fig. 8c). In turn, location of the main morphological northern front of the paleo- Tian Shan, during Latest Jurassic to Early Cretaceous, would approximately coincide with the one of the current range front (Fig. 5). The uplift documented by these coarse-grained sedimentary breccias is also recorded by AFT chronology studies; Fissiontrack modeling indicates a ca. 160 and 120 Ma cooling age along a Dushanzi-Kuqa corridor, in the mountain interior (Dumitru et al., 2001; Jolivet et al., 2010). Apatite sampled from Bayanbulak area yields the earliest cooling ages of Early Cretaceous (Dumitru et al., 2001; Wang et al. 2009).

Because no major tectonic event occurred in the Northern Tian Shan during Mesozoic times (e.g. De Grave et al., 2007), the Paleozoic subduction-collision orogeny (Gao et al., 1998; Laurent-Charvet et al., 2002; Charvet et al., 2007) appears as the most probable origin of the Mesozoic paleorelief above described. In such case, the Tian Shan would persist as remnant relieves for several tens of Ma after the end of the orogenic events which are progressively and unconformably overlain by Triassic and then Jurassic sedimentation (e.g. onlap structures, mesoscale paleorelief infilling). This scenario implies extremely low erosion rates to allow the preservation of a significant relief; such feature has already been reported for other regions of Central Asia from thermochronological (AFT) and field data analyses (Jolivet et al., 2007). In parallel, Central Asia Mesozoic tectonic history is marked by the polyphased Cimmerian orogeny in Tibet area (e.g. Hendrix et al., 1992; Sobel and Dumitru, 1997; De Grave et al., 2007). Low amplitude, far-field effects can thus be recognized in the 
Mesozoic northern Tian Shan: one early collision stage - Qiantang/Kunlun blocks during Late Triassic/Middle Jurassic - would correspond to the drastic coarsening of the Lower Jurassic sedimentation. In turn, a later collision stage - Lhasa/Qiantang blocks during Late Jurassic/Early Cretaceous - well corresponds to the deposits of the thick and coarse breccias of the Kalaza Fm. at that time. In this case, a tectonic origin of the relief rejuvenation is attested by a major angular unconformity observed regionally.

As unambiguously demonstrated, the physiography of the modern Tian Shan dominantly results from the recent tectonic evolution of the area (e.g. Tapponnier and Molnar, 1977; Avouac et al., 1993; Métivier and Gaudemer, 1997; Charreau et al., 2009). However, this study put forward that the current Tian Shan topography can probably not be considered as the consequence of the Cenozoic intracontinental reactivation alone, but as a combination of the Cenozoic deformations superimposed on a reminiscent Mesozoic paleo-range. These new results question on the amplitude of the movements that could be estimated along the northern front structures during Cenozoic intracontinental reactivation.

\section{Acknowledgements}

Field and laboratory work in the present study are financially supported by Chinese National 973 Program (2009CB825008) and Chinese National S\&T Major Project 2011ZX05008.

Prof. A.R. Caroll, Dr. J. Charreau, and an anonymous reviewer are warmly thanked for their constructive reviews. We are also grateful for the help by Prof. Carlo Doglioni (Editor) and Prof. Gerhard Wörner (Associate Editor). Discussions on seismic profiles' interpretation with

Dr. Y. Branquet have also been greatly appreciated. The first author benefices a Ph.D scholarship from French Embassy in Beijing and IGGCAS. 


\section{References}

Abdrakhmatov, K.Y., Aldazhanov, S.A., Hager, B.H., Hamburger, M.W., Herring, T.A., Kalabaev, K.B., Makarov, V.I., Molnar, P., Panasyuk, S.V., Prilepin, M.T., Reilinger, R.E., Sadybakasov, I.S., Souter, B.J., Trapeznikov, Y.A., Tsurkov, V.Y. and Zubovich, A.V., 1996. Relatively recent construction of the Tien Shan inferred from GPS measurements of presentday crustal deformation rates. Nature, 384, 450-453.

Allen, M.B., Windley, B.F., Zhang, C., Zhao, Z.Y. and Wang, G.R., 1991. Basin Evolution within and Adjacent to the Tien-Shan Range, NW China. J. Geol. Soc. London, 148, 369-378.

Avouac, J.P., Tapponnier, P., Bai, M., You, H. and Wang, G., 1993. Active Thrusting and Folding Along the Northern Tien-Shan and Late Cenozoic Rotation of the Tarim Relative to Dzungaria and Kazakhstan. J. Geophys. Res., 98, 6755-6804.

Burchfiel, B.C., Brown, E.T., Deng, Q.D., Feng, X.Y., Li, J., Molnar, P., Shi, J.B., Wu, Z.M. and You, H.C., 1999. Crustal shortening on the margins of the Tien Shan, Xinjiang, China. Int. Geol. Rev., 41, 665-700.

Burov, E.B., Lobkovsky, L.I., Cloetingh, S. and Nikishin, A.M., 1993. Continental lithosphere folding in Central Asia (Part II): constraints from gravity and topography. Tectonophysics, 226, 73-87.

Carroll, A.R., Liang, Y., Graham, S.A., Xiao, X., Hendrix, M.S., Chu, J., and McKnight, C.L., 1990. Junggar basin, northwest China: Trapped late Paleozoic ocean. Tectonophysics, 181, 114. 
Carroll, A. R., Graham, S.A., Hendrix, M.S., Ying, D., and Zhou, D., 1995. Late Paleozoic tectonic amalgamation of northwestern China: sedimentary record of the northern Tarim, northwestern Turpan, and southern Junggar basins. Geol. Soc. Am. Bull., 107, 571-594.

Carroll, A.R., Graham, S.A. and Smith, M.E., 2010. Walled sedimentary basins of China. Basin Res., 22, 17-32.

Charreau, J., Chen, Y., Gilder, S., Barrier, L., Dominguez, S., Augier, R., Sen, S., Avouac, J.P., Gallaud, A., Graveleau, F. and Wang, Q.C., 2009. Neogene uplift of the Tian Shan Mountains observed in the magnetic record of the Jingou River section (northwest China). Tectonics, 28, TC2008, doi:10.1029/2007TC002137.

Charvet, J., Shu, L.S. and Laurent-Charvet, S., 2007. Paleozoic structural and geodynamic evolution of eastern Tianshan (NW China): welding of the Tarim and Junggar plates. Episodes, 30, 162-186.

Cloetingh, S., Burov, E. and Poliakov, A., 1999. Lithosphere folding: primary response to compression? (from central Asia to Paris basin). Tectonics, 18, 1064-1083.

De Grave, J., Buslov, M.M. and Van den Haute, P., 2007. Distant effects of India-Eurasia convergence and Mesozoic intracontinental deformation in Central Asia: Constraints from apatite fission-track thermochronology. J. Asian Earth Sc., 29, 188-204.

Deng, Q.D., Zhang, P.Z., Xu, X.W., Yang, X.P., Peng, S.Z., and Feng, X.Y., 1996. Paleoseismology of the northern piedmont of Tianshan Mountains, northwestern China. $J$. Geophys. Res., 101, 5895-5920.

Dumitru, T.A., Zhou, D., Chang, E.Z., Graham, S.A., Hendrix, M.S., Sobel, E.R., and Caroll, A.R., 2001. Uplift, exhumation, and deformation in the Chinese Tian Shan. in: Paleozoic and 
Mesozoic tectonic evolution of central Asia: From continental assembly to intracontinental deformation (Hendrix, M.S., and Davis,G.A., eds). Geol. Soc. Am. Mem., 194, 71-99.

Gao, J., Li, M.S., Xiao, X.C., Tang, Y.Q. and He, G.Q., 1998. Paleozoic tectonic evolution of the Tianshan Orogen, northwestern China. Tectonophysics, 287, 213-231.

Graham, S.A., Hendrix, M.S., Wang, L.B. and Carroll, A.R., 1993. Collisional successor basins of western China Impact of tectonic inheritance on sand composition. Geol. Soc. Am. Bull., 105, 323-344.

Han B.F., He, G.Q. and Wang, S., 1999. Postcollisional mantle-derived magmatism, underplating and implications for basement of the Junggar Basin. Sci. China. Ser. D, 42, 113119.

Hendrix, M.S., Graham, S.A., Carroll, A.R., Sobel, E.R., Mcknight, C.L., Schulein, B.J., and Wang, Z.X., 1992. Sedimentary Record and Climatic Implications of Recurrent Deformation in the Tian-Shan - Evidence from Mesozoic Strata of the North Tarim, South Junggar, and Turpan Basins, Northwest China. Geol. Soc. Am. Bull., 104, 53-79.

Hendrix, M.S., Dumitru, T.A. and Graham, S.A., 1994. Late Oligocene Early Miocene Unroofing in the Chinese Tien-Shan - an Early Effect of the India-Asia Collision. Geology, 22, 487-490.

Hendrix, M.S., 2000. Evolution of mesozoic sandstone compositions, southern Junggar, northern Tarim, and western Turpan basins, northwest China: A detrital record of the ancestral Tian Shan. J. Sed. Res., 70, 520-532.

Huang, B. and Li, J., 2007. Sporopollen assemblages from the Xishanyao and Toutunhe formations at the Honggou section of the manasi river, xinjiang and their stratigraphical significance. Acta Micropaleontologica Sinica, 24, 170-193. 
Jolivet, M., Ritz, J.F., Vassalo, R., Larroque, C., Braucher, R., Todbileg, M., Chauvet, A., Sue, C., Arnaud, N., de Vicente, R., Arzhanikova, A. and Arzhanikova, S., 2007. Mongolian summits: An uplifted, flat, old but still preserved erosion surface. Geology, 35, 871-874.

Jolivet, M., Dominguez J., Charreau J., Chen, Y., Farley, K.A., Li, Y.A. and Wang, Q.C., 2010. Mesozoic and Cenozoic tectonic history of the Central Chinese Tian Shan: Reactivated tectonic structures and active deformation. Tectonics, 29, TC6019, doi:10.1029/2010TC002712.

Laurent-Charvet S., Charvet, J., Shu, L.S., Ma, R.S. and Lu, H.F., 2002. Late Paleozoic collisional strike-slip deformations in Tianshan and Altay, eastern Xinjiang, NW China. Terra Nova, 14, 249-256.

Li Z., Zhang L., Qian C., Wang Y. and Bai G., 1978. Regional geological survey report of Geological map 1:200000, Shichang sheet. China Ministry of Geology and Mineral Resource, Beijing.

Li, Z., Song, W.J., Peng, S.T., Wang, D.X. and Zhang, Z.P., 2004. Mesozoic-Cenozoic tectonic relationships between the Kuqa subbasin and Tian Shan, northwest China: constraints from depositional records. Sed. Geol., 172, 223-249.

Liu, Z., 1990. Sporo-pollen assemblage from Middle Jurassic Xishanyao Formation of Shawan, Xinjiang, China. Acta Palaeontologica Sinica, 29, 63-82.

Lu Y.Z. and Deng S.W., 2005. Triassic-Jurassic Sporopollen Assemblages on the Southern Margin of the Junggar Basin, Xinjiang and the T-J Boundary. Acta Geologica Sinica, 79, 1528. 
Martinod, J., and Davy, P., 1992. Periodic instabilities during compression of the lithosphere 1. Deformation modes from an analytical perturbation method. J. Geophys. Res., 92, 19992014.

Martinod, J. and Davy, P., 1994. Periodic instabilities during compression of the lithosphere 2. Analogue experiments. J. Geophys. Res., 99, 12057-12069.

Métivier, F. and Gaudemer, Y., 1997. Mass transfer between eastern Tien Shan and adjacent basins (central Asia): Constraints on regional tectonics and topography. Geophys. J. Int., 128, $1-17$.

Sengör, A.M.C., Natal'in, B.A., Burtman, V.S., 1993. Evolution of the Altaid tectonic collage and Paleozoic crust growth in Eurasia. Nature, 364, 299-307.

Sobel, E.R. and Dumitru, T.A., 1997. Thrusting and exhumation around the margins of the western Tarim basin during the India-Asia collision. J. Geophys. Res., 102, 5043-5063.

Tapponnier, P. and Molnar, P., 1977. Active Faulting and Tectonics in China. J. Geophys. Res., 82, 2905-2930.

Wang, B. Chen, Y., Zhan, S., Shu, L.S., Faure, M., Cluzel, D., Charvet, J. and LaurentCharvet, S., 2007. Primary Carboniferous and Permian paleomagnetic results from the Yili Block (NW China) and their implications on the geodynamic evolution of Chinese Tian Shan Belt. Earth Planet. Sci. Lett., 263, 288-308.

Wang, Q. C., Li S. J. and Du z. L., 2009. Differential uplift of the Chinese Tian Shan since the Cretaceous: constraints from sedimentary petrography and apatite fission-track dating. Int. J. Earth Sci., 98, 1341-1363. 
Wang, X.W., Wang, X.W., Liu, J.P., Liu, J.P. and Ma, Y.S., 2005. Analysis of the fold-thrust zone in the southern Junggar Basin, north western China. Earth Science Frontiers, 12, 411421.

Wang, Z., Wu, J., Lu, X., Liu, C., and Zhang, J., 1990, Polycyclic tectonic evolution and metallogeny of the Tian Shan mountains. Beijing, Science Press.

Windley, B.F., Allen, M.B., Zhang, C., Zhang, C., Zhao, Z.Y. and Wang, G.R., 1990. Paleozoic accretion and Cenozoic redeformation of the Chinese Tien Shan range, Central Asia. Geology, 18, 128-131.

XBGMR-WUSU, 1973, Bureau of Geological and Mineral Resources of Xinjiang Uygur Autonomous Region, Geological map of Wusu Region, Scale 1:200.000, China Ministry of Geology and Mineral Resource, Beijing.

XBGMR-HOUXIA, 1977, Bureau of Geological and Mineral Resources of Xinjiang Uygur Autonomous Region, Geological map of Houxia Region, Scale 1:200.000, China Ministry of Geology and Mineral Resource, Beijing.

XBGMR-SHICHANG, 1978, Bureau of Geological and Mineral Resources of Xinjiang Uygur Autonomous Region, Geological map of Shichang Region, Scale 1:200.000, China Ministry of Geology and Mineral Resource, Beijing.

XBGMR, 1993, Regional geology of Xinjiang Uygur autonomy region.- Geological Memoirs, Ser. 1, No. 32, Map Scale 1: 1.500.000, Geological Publishing House, Beijing.

Yang, J., and Sun, S., 1982. The discovery of Early and Middle Jurassic megaspores from the Junggar Basin, Xinjiang, and their stratigraphic significance. Acta Geologica Sinica, 4, 375379. 
Yang, J.L, Wang Q.F. and Lu H.N., 2005, Discovery of cretaceous and Paleocene charophyte floras from well $\mathrm{Hu}-2$ in the southern edge of Junggar basin. Acta Micropalaeontologica Sinica, 22, 251-268. 


\section{Figure captions}

Fig. 1 Simplified geological map of the northern Tian Shan from Wusu to Urumqi areas. Mesozoic is most exposed in the southernmost parts of the Junggar basin along the adjacent Tian Shan range, particularly to the East (Urumqi area). 'He' indicates river in Chinese (modified after XBGMR, 1993).

Fig. 2 Synthetic and representative stratigraphic log made in the Manasi He area, northern Tian Shan piedmont, where Cenozoic have been widely eroded (modified after Hendrix et al., 1992).

Fig. 3 Landscape pictures of representative features of the Mesozoic sedimentary series (see locations on Fig.1) (a) Coarse-grained conglomerate of lowermost Jurassic forming prominent bars in the landscape (southern Qingshui He area); (b) Uppermost Jurassic coarse-grained breccias (Kalaza Fm. - $\mathbf{J}_{3 \mathrm{k}}$ ) unconformably overlying the Upper Jurassic Qigu formation $\left(\mathrm{J}_{3 \mathrm{q}}\right.$; Hutubi He area); (c) Close-up view of the Uppermost Jurassic Kalaza Fm. breccias (west to Hutubi He area). Note the angular shape of the clasts (locally exceeding $50 \mathrm{~cm}$ ) and the clastsupported character of the coarser levels.

Fig. 4 Structural and sedimentological observations in the Houxia area. (a) Simplified geological map with some field structural measurements (modified after XBGMR, 1977), (b) detailed geological cross-section across the northern limb of the syncline structure (see location on Fig. 4a), (c) Close-up view of the Lower Jurassic breccias including Carboniferous basement angular clasts (see location on Fig. 4b), (d) picture of the steep bedding of Jurassic layers close to the southward thrust (see location on Fig. 4b).

Fig. 5 (a) Simplified geological map of the Hutubi He area (modified after XBGMR, 1978, 1993) with few structural measurements from field work. 'A' indicates location where Middle 
Jurassic deposits directly and unconformity lie onto Carboniferous basement without Triassic or Lower Jurassic, (b) Geological cross-section along the Hutubi He constrained by field data, seismic profile (after Wang et al., 2005) and nearby drill wells W1 and W1'. Location of the section is indicated on Fig. 5a. Extension of the available seismic profile is indicated on the section.

Fig. 6 Examples of onlap structures of the Jurassic sediments over the Paleozoic basement units. (a) Picture and interpretation field sketch of the southern part of the Hutubi He (see location on Fig. 5a): note the overall southward onlap of the Jurassic sediments over the folded basement. To the north, a basement block is back thrusted over the sediments (see Fig. 5b), (b) Picture and interpretation field sketch of a small valley, west of the Hutubi He (see location on Fig. 5a): meso-scale basement relief covered by Jurassic sandstones as evidenced by onlaps over a steep inherited $\sim 150$ m high basement paleorelief (scarp). Basement rocks are deformed with a large inclined Paleozoic fold.

Fig. 7 Structural and sedimentological observations in the Wusu area. (a) Simplified geological map (modified after XBGMR, 1973) with few structural measurements. (b) Geological cross-section constrained by field data, seismic profile and drill well W2 (see Fig. 7a for location). (c) Picture and corresponding field sketch interpretation of the unconformable contact between Jurassic layers and the Carboniferous basement (see Fig. 7a for location).

Fig. 8 Sketch views of the paleogeographic evolution of the northern piedmont of Tian Shan during Early, Middle and Upper Jurassic/Cretaceous boundary. Main observations that constrain this study are localized on the drawings as: A for Fig. 3a; B for Fig. 4c (lower Jurassic sedimentary breccias); C for Fig. 6a (onlap covering of Paleozoic basement rocks by 
Jurassic sandstones) and D for Figs. 3b and 3c (thick Kalaza Fm. breccias with angular discordance at the base). 


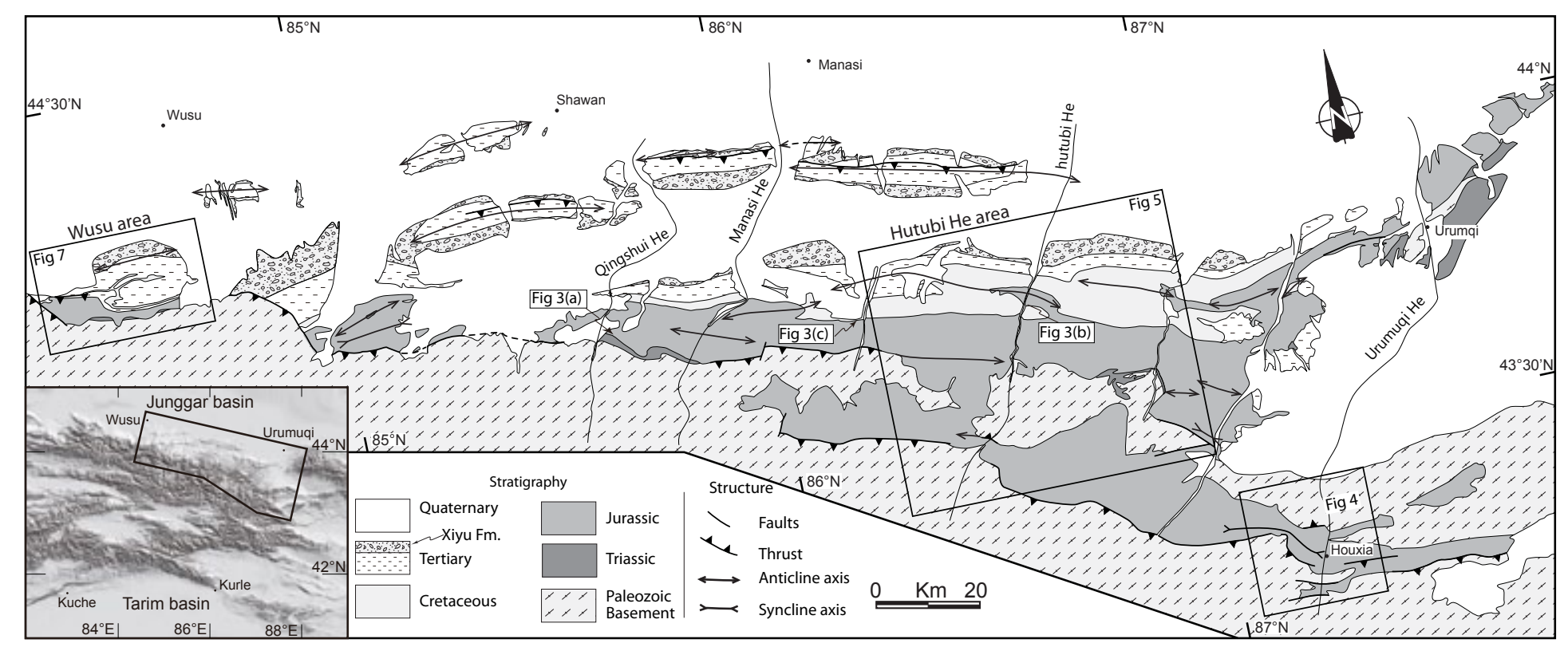

Fig 1. 


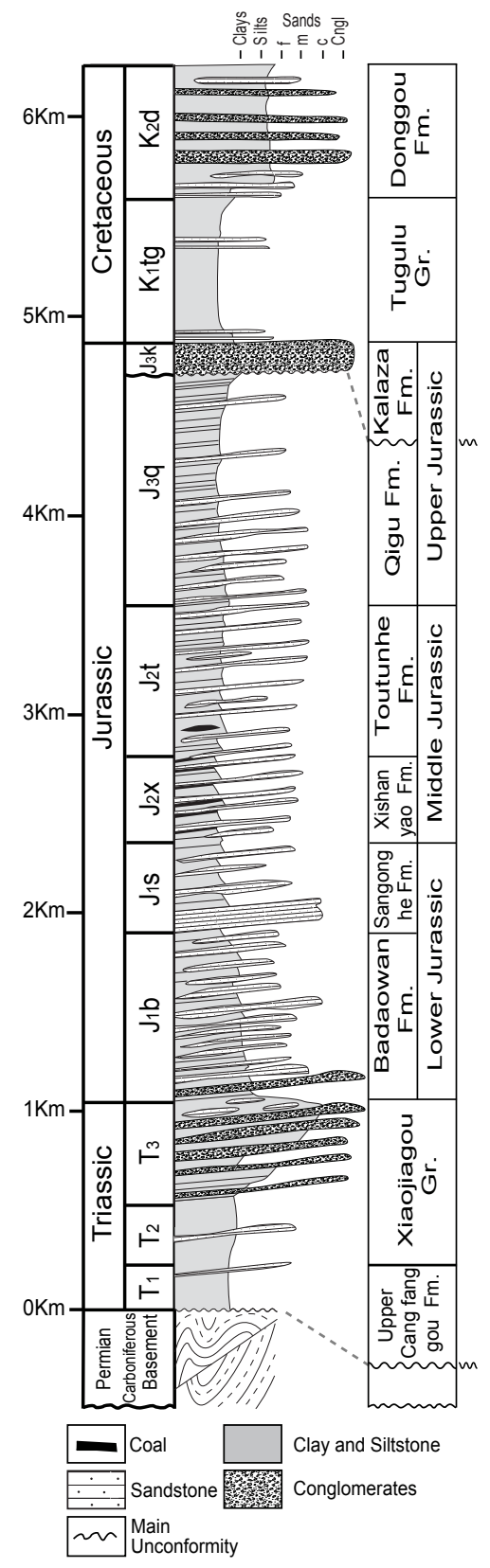

Fig 2. 

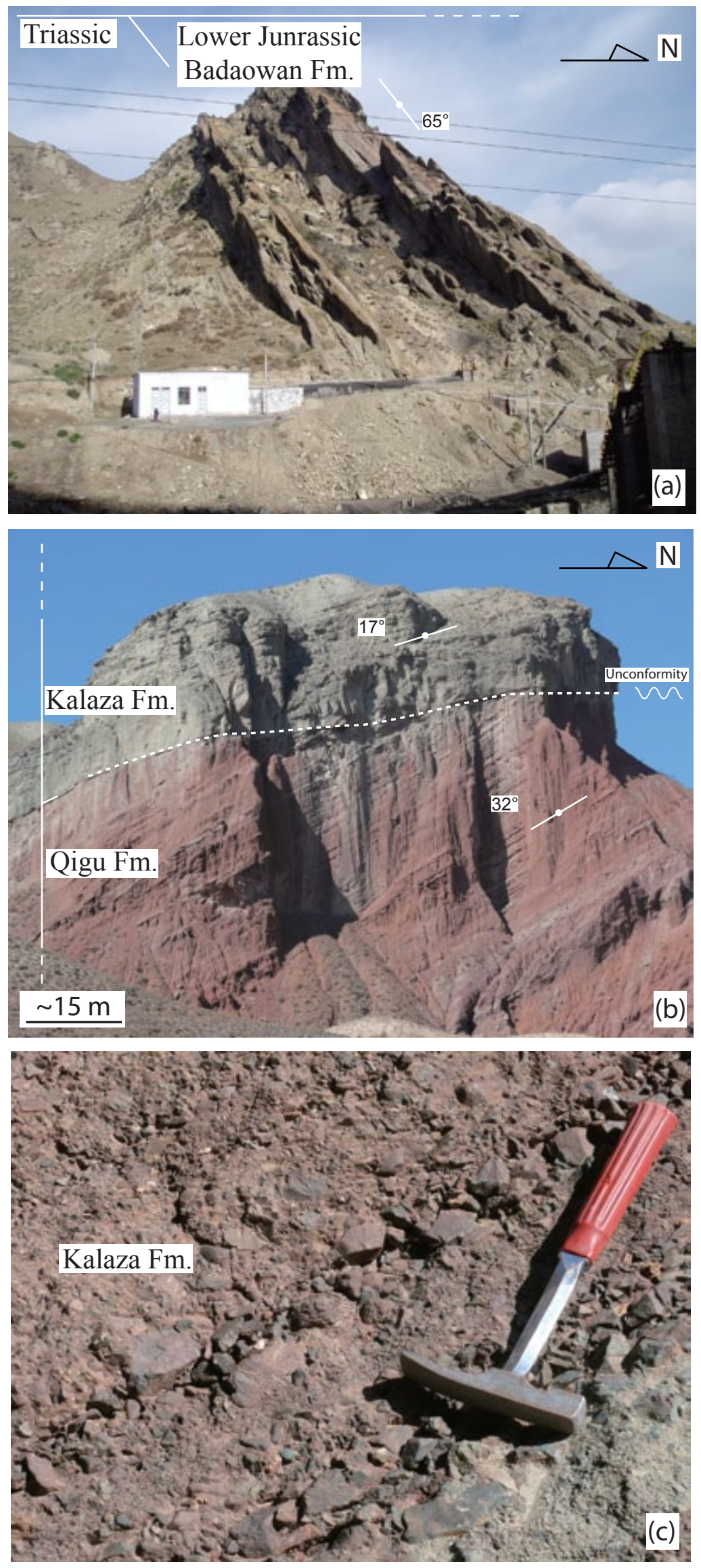

Fig 3. 

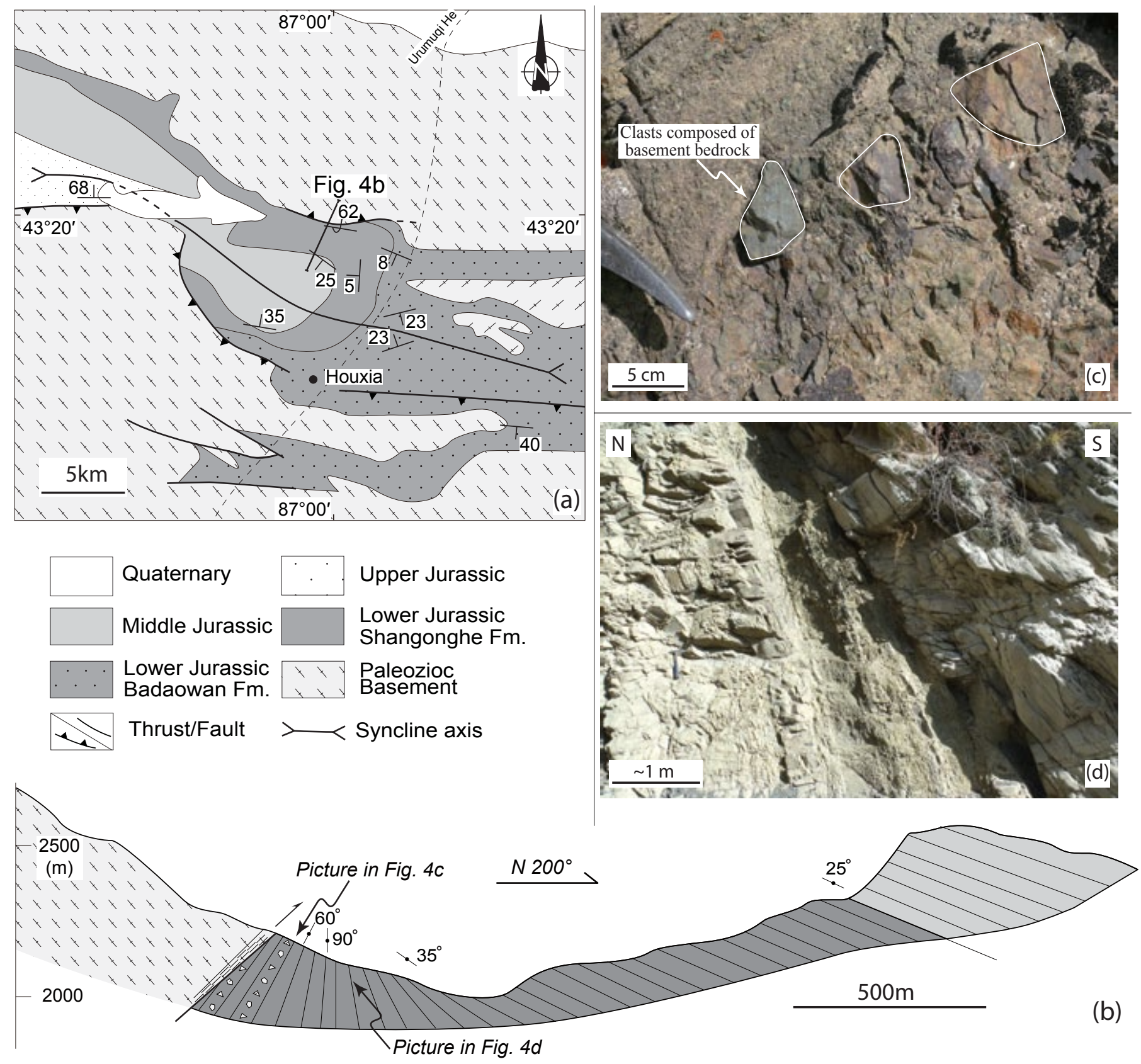

Fig 4. 


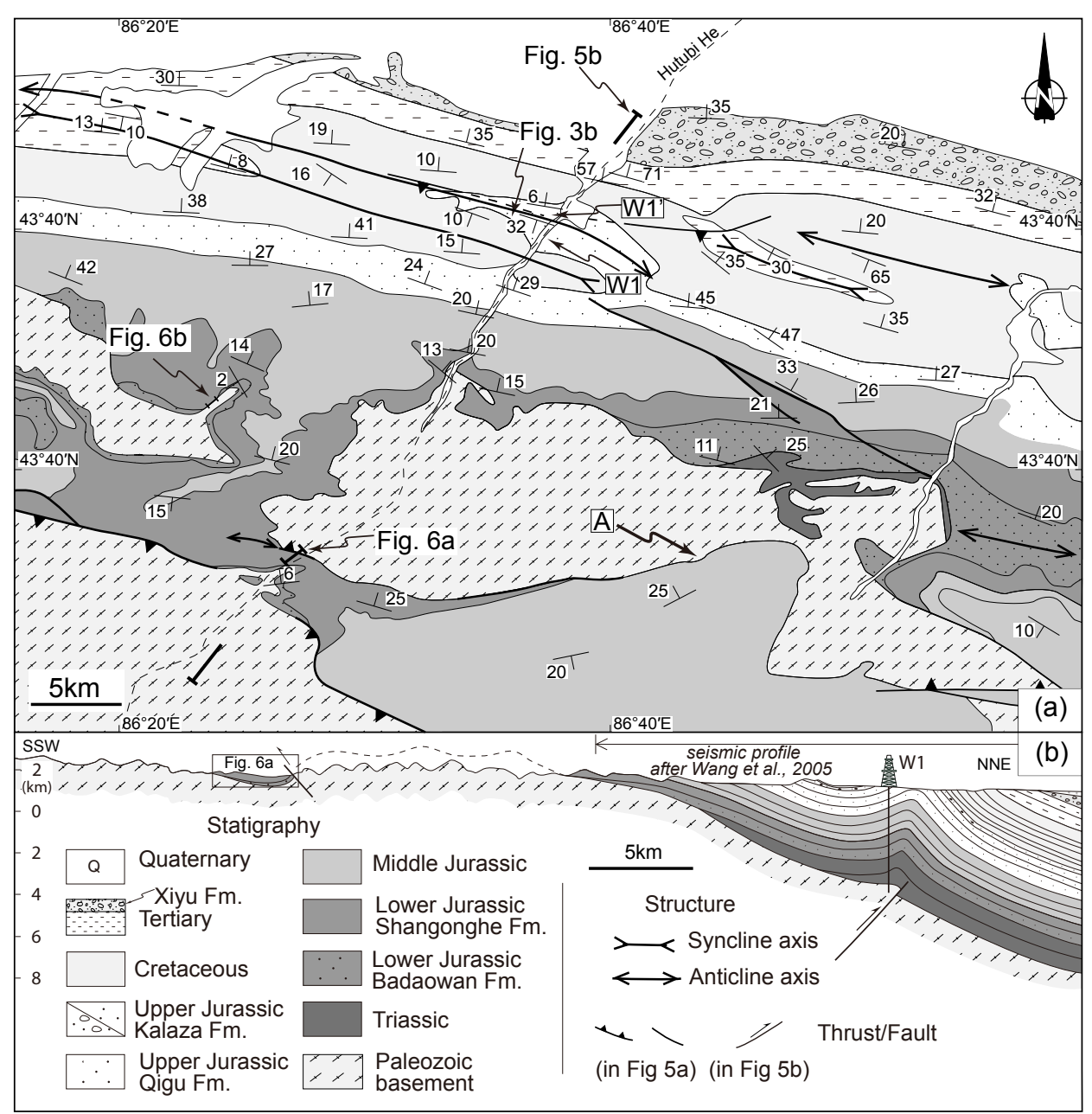

Fig 5. 

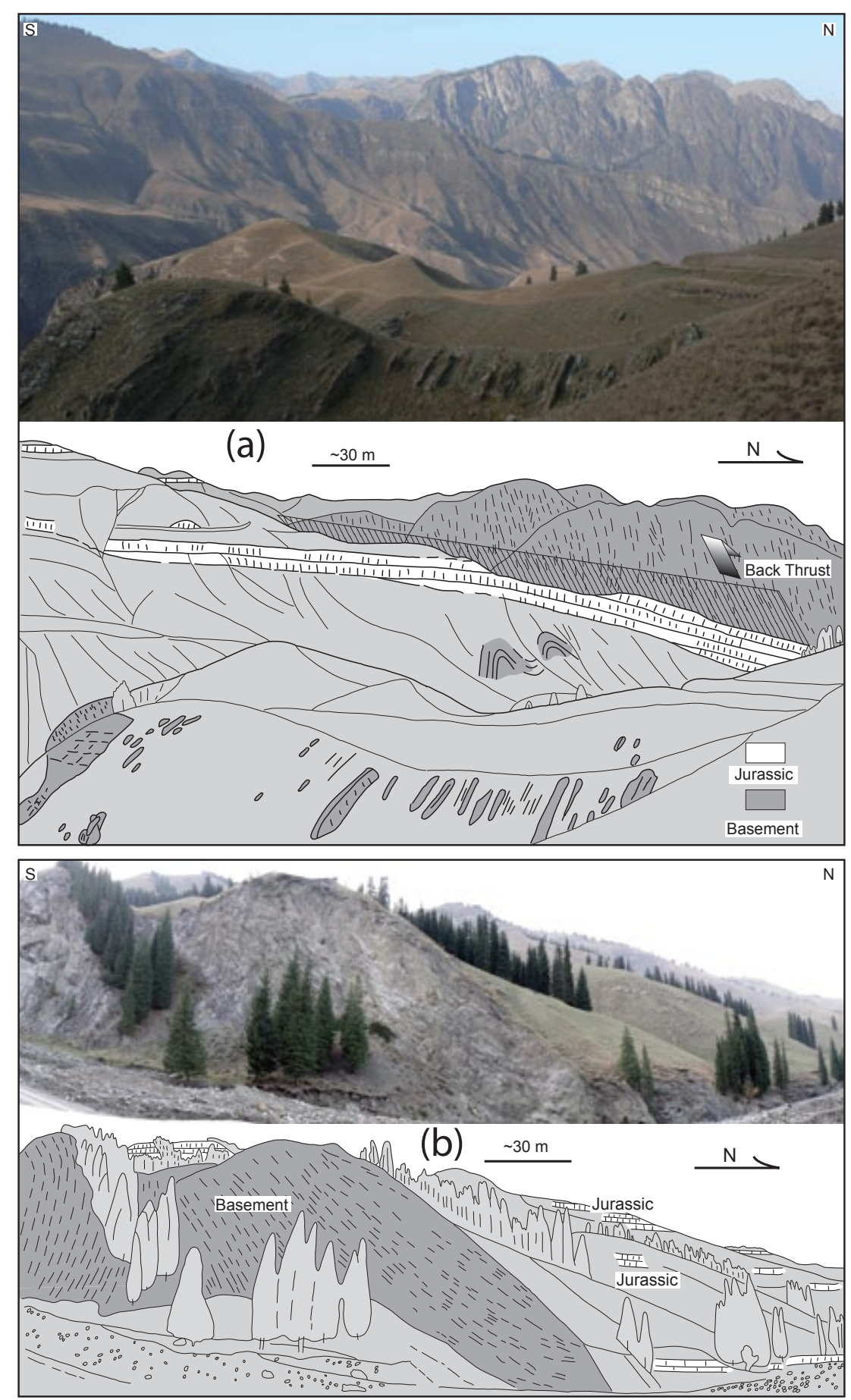

Fig 6. 


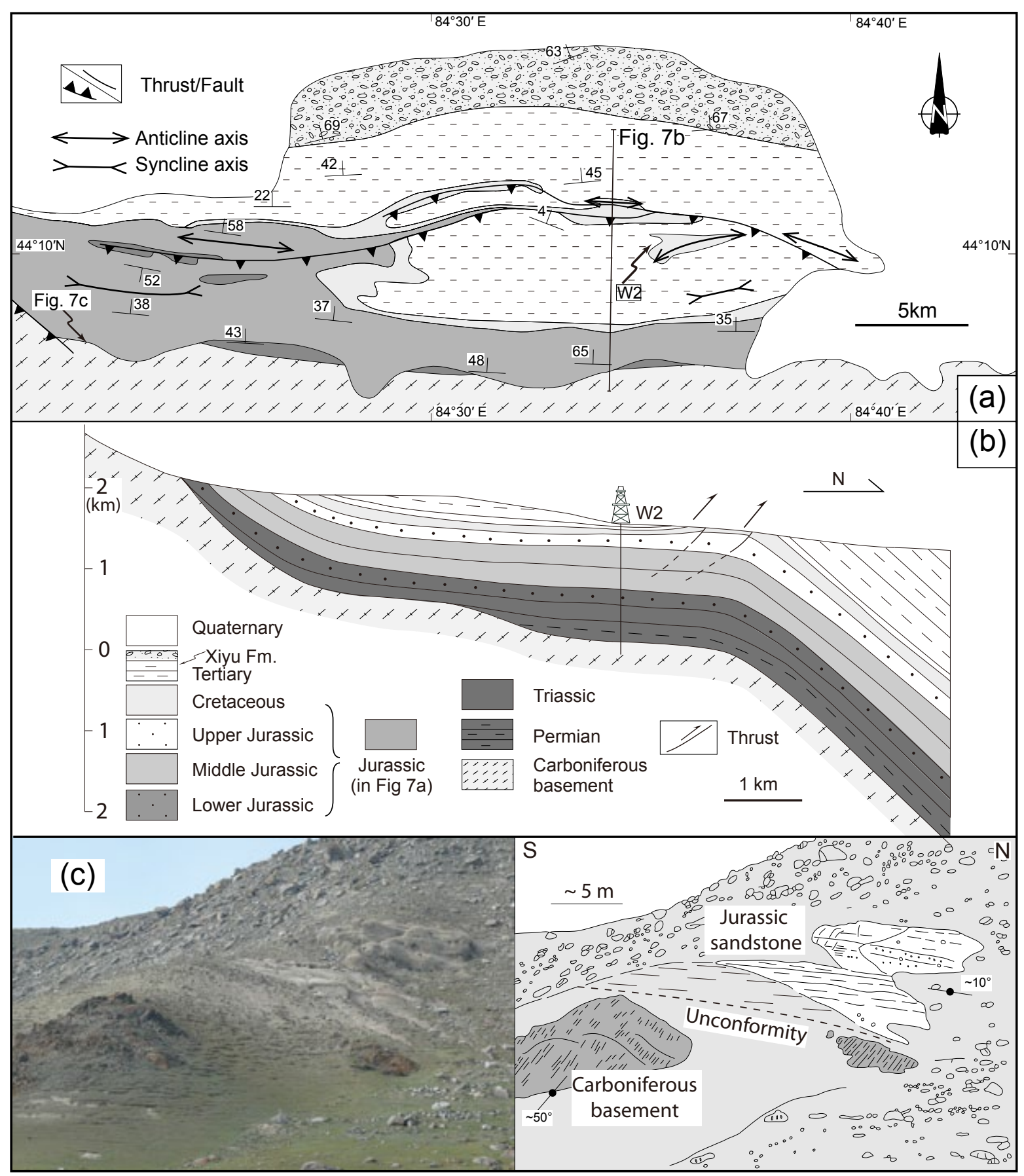

Fig 7. 


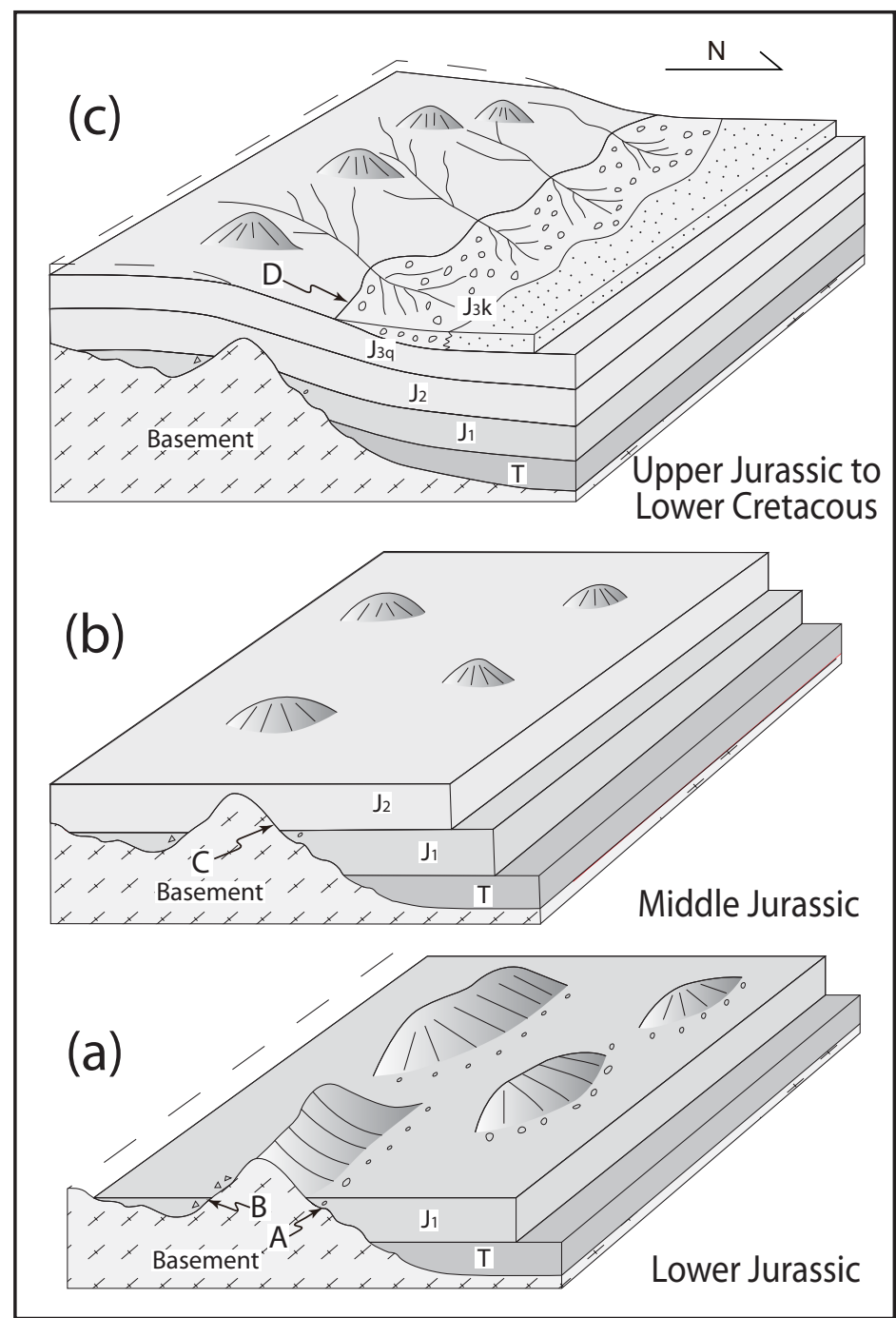

Fig 8. 


\section{The Mesozoic paleorelief of the northern Tian Shan (China)}

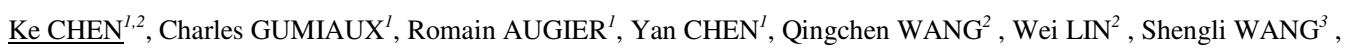

1. Institut des Sciences de la Terre d'Orléans (ISTO), Université d'Orléans, CNRS: UMR6113, Université François Rabelais - Tours, - INSU,

Campus Géosciences, 1A rue de la Férollerie, 45071 Orléans cedex 2, France

2. State Key Laboratory of Lithospheric Evolution, Institute of Geology and Geophysics, Chinese Academy of Sciences, P.O. 9825, Beijing 100029, China

3. Department of Earth Sciences, Nanjing University, 210093, Nanjing, China

\section{Abstract}

The Tian Shan range offers a natural laboratory to study orogenic processes. Most of the previous studies focused on either the Paleozoic evolution of the range or its Cenozoic intracontinental evolution linked with the India-Asia collision. In this study, detailed field investigations on the relationship between sedimentary cover and basement constrain the Mesozoic evolution of the northern Tian Shan. Sedimentological observations argue for limited transport distance for Lower and Uppermost Jurassic deposits. Geological sections presented in this paper show that, in preserved locations, Triassic to Jurassic sedimentary series present a continuous onlap type sedimentary unconformity on the top of the basement. At different scales, observations clearly evidence the existence of a major paleorelief during Mesozoic. According to the present study, the current Tian Shan range topography and the associated movements along its northern front structures cannot be considered as the consequence of Cenozoic reactivation alone.

\section{Keywords}

Tian Shan, paleorelief, Mesozoic, regional onlap, reactivation, India-Asia collision. 


\section{Introduction}

The modern Tian Shan is one of the major mountain ranges in Central Asia. The current structure of Tian Shan mainly results from a combination of two main tectonic events: i) subductions, arc-accretions and continental collision during Paleozoic (e.g. Carroll et al., 1990; Wang et al., 1990; Windley et al., 1990; Sengör et al. 1993; Carroll et al., 1995; Gao et al., 1998; Laurent-Charvet et al., 2002; Charvet et al., 2007; Wang et al., 2007) and ii) intracontinental reactivation linked to the India-Asia collision, during Cenozoic (e.g. Tapponnier and Molnar, 1977; Avouac et al., 1993). At first order, the modern Tian Shan corresponds to a raised east-west trending Paleozoic 'basement' range, flanked by two closed intracontinental basins whose infill is a particularly accurate record for both tectonic and climate evolutions (Fig. 1). The present-day high topography of Tian Shan, with a mean altitude of $\sim 2500 \mathrm{~m}$ and summits of more than $7000 \mathrm{~m}$, is traditionally related to the latest intracontinental deformation of the range (e.g. Tapponnier and Molnar, 1977; Avouac et al., 1993; Burchfiel et al., 1999). Age constraints for the onset of this intracontinental reactivation range from 10 to $24 \mathrm{Ma}$ (e.g. Avouac et al., 1993; Hendrix et al., 1994; Abdrakhmatov et al., 1996; Métivier and Gaudemer, 1997; Sobel et al., 1997; Dumitru et al., 2001; Charreau et al., 2009). In spite of relative age discrepancies (mostly related to the method applied), all ages estimated for the deformation and the associated relief erosion suggest that the mountain range reactivation and relief creation began during Early Miocene at oldest.

However, recent Fission-track analyses suggest that uplifting may have existed well before the onset of the Tertiary reactivation through Tian Shan, with exhumation ages such as 160-120 Ma in central Tian Shan, 200-250 Ma detritus cooling age in the Manas River valley (Dumitru et al., 2001; Jolivet et al., 2010) or 140-120 Ma from Bayanbulak intracontinental basin, in the southern Tian Shan (Wang et al., 2009). Moreover, Triassic to Cretaceous sediments are composed of thick continental series characterized by massive coarse-grained 
formations within both basins, suggesting rather high erosion rate at that time (Hendrix, 2000; Carroll et al., 2010).

This study considers the Mesozoic tectonic and morphologic evolution of Tian Shan through field structural and sedimentological analyses of Mesozoic deposits. It focuses on the northern piedmont of the range, along a $\sim 280 \mathrm{~km}$ west-east trending segment (Fig. 1). Thanks to deep incisions of seasonal rivers, contacts between Paleozoic basement and MesozoicCenozoic sedimentary cover are particularly well exposed along several north-south trending sections in this region (Fig. 1). Such new constraints on Mesozoic evolution of the Tian Shan area would lead to reconsider the contribution of Cenozoic tectonics in the modern mountain range building as well as to better quantify the net shortening amount during that period.

\section{Stratigraphy of the Mesozoic sediments within the study area}

Sedimentary series can be extensively observed and have already been studied within the Junggar basin, as summarized below (Figs. 1 and 2; Hendrix et al., 1992 and references therein; XBGMR, 1993). Basement units of the north Tian Shan mainly consist of Paleozoic volcanic and sedimentary rocks. From bottom to top, the entire Mesozoic series is composed of $\sim 5 \mathrm{~km}$ thick continental clastic deposits highlighting high sedimentation/preservation rates (Fig. 2). Thanks to numerous studies aimed at oil and gas exploration and to 1:200.000 mapping projects hold in this area, ages of the Mesozoic sequences were mainly constrained by floral and sporopollen assemblage analyses (Li et al., 1978; Yang et al., 1982; Liu, 1990; XBGMR, 1993; Lu and Deng, 2005; Yang et al., 2005; Huang and Li, 2007). In the study area, the Triassic series are mostly missing along the piedmont though locally exposed (Fig. 1). Where it crops out, Triassic displays alluvial sandstones and conglomerates intercalated within and silty mudstones (red-beds). At the scale of the northern Tian Shan piedmont, Lowermost Jurassic layers indicate a change in the sedimentation as they consist in thick and 
coarse conglomeratic deposits, as exposed in the south of Qingshui He (Fig. 3a). Thickness of Lower Jurassic reaches $1000 \mathrm{~m}$ over the area extending from Manasi to Urumqi, and decreases westwardly and eastwardly. Sediments become progressively finer upward, grading into $\sim 3 \mathrm{~km}$ thick series of Lower/Middle Jurassic gray sandstones, silty shales (Fig. 2). Middle Jurassic sandstones and mudstones locally contain coal-rich layers consistent with a lacustrine depositional facies (Hendrix et al., 1992). Upper Jurassic comprises typical finegrained red beds where conglomerates remain scarce. The transition from Jurassic to Cretaceous series is marked by up to $800 \mathrm{~m}$ thick sedimentary breccias (Kalaza formation J3k; Fig. 3b) made of coarse-grained angular clasts (Fig. 3c). It rapidly dies laterally and grades to sandstones within the Junggar basin itself (XBGMR, 1978; 1993). The marked unconformity between the Kalaza formation and the underlying finer-grained Upper Jurassic red beds (Fig. 3b) suggests a short transport distance of material before deposition and nearby relief uplifting.

In this study, Mesozoic sediments have also been extensively observed within internal parts of the range, and more particularly in the eastern part of the studied area (Fig. 1). Triassic to Jurassic sediments are encountered on top of the Paleozoic basement units, at rather high altitudes (2000 to $3000 \mathrm{~m}$ ) in comparison with the mean altitude of the foreland fold-and-thrust belts (1000 to $1500 \mathrm{~m}$ high). In the Houxia valley for instance - $65 \mathrm{~km} \mathrm{SSW}$ of Urumqi - a Lower to Upper Jurassic continuous sedimentary series is preserved in a syncline structure (Fig. 4a). According to the geological map (Fig. 4a; XBGMR, 1977), Lower Jurassic formations - i.e. Shangonghe Fm. to the northwest and Lowermost Jurassic Badaowan Fm. to the east - directly overlie on top of Carboniferous basement units, without intercalated Triassic sediments. Besides, south and north verging thrusts developed along parts of the northern and southern limbs of the fold, respectively (Fig. 4a). A section made across the north limb of the syncline displays continuous Lower to Middle Jurassic series with 
no fault contact observed (Fig. 4b). From south to north, bedding planes progressively straighten up from $\sim 30^{\circ}$ south dipping to vertical, and even overturned just below the south verging thrust (Figs. $4 \mathrm{a}, 4 \mathrm{~b}$ and $4 \mathrm{~d}$ ). From a sedimentological point of view, the upper and main part of Jurassic series is made of fine-grained sandstones and mudstones while the lowermost deposits of the series is characterized by intercalations of coarse-grained sedimentary breccias mostly made of highly angular clasts of Carboniferous tuffaceous sandstones (Fig. 4c). Local abundance of these breccias and the common lithological nature of the clasts with the adjacent basement unit strongly suggest a very short transport distance.

\section{Structural analysis of the Mesozoic basal contact} analysis of sedimentary series, within the Cenozoic foreland basin (e.g. Avouac et al., 1993; Deng et al., 1996; Burchfiel et al., 1999). This part focuses on the basal contact of the Mesozoic sediments, in the northern "front" area of Tian Shan.

As shown on the map (Fig. 1), some parts of the piedmont display northward thrusts that mark out the boundary in between the Paleozoic uplifted basement units and relatively subsiding proximal foreland basin. Yet, as described above, Mesozoic series are not solely restricted to the piedmont fold-and-thrust belts but are also well preserved on top of the basement units, within the range (Fig. 1). Then, some other segments of the piedmont display perfectly continuous Mesozoic sedimentary series from basin until internal and higher parts of the range, without being strained by any faulting or folding in the range front area (Fig. 1). Structural analysis of such unstrained basal contact of Mesozoic series is presented for two of the sections constructed from field work combined with available seismic profiles and drillholes data: the Hutubi He and the Wusu sections (Fig. 1). 
At first order, to the north of the Hutubi He area, Triassic to Neogene sedimentary

series form a rather simple monocline structure, dipping $15-20^{\circ}$ to the north (Fig. 5a). The southernmost fold-and-thrust belt is composed of one gentle upright anticline and associated syncline with only very limited thrusts developed along the hinge of the fold (Fig. 5a). This belt can be regarded as a fault-propagation fold structure according to the available seismic profile (Wang et al., 2005; Fig. 5b). Further south, entering within the interior parts of the range, sub-horizontal Lower Jurassic strata lie on top of the Carboniferous units (Fig. 5b). While basement is strongly deformed, as evidenced by sub-vertical cleavage, its sedimentary cover is only gently folded as illustrated on the geological map, few kilometers west of the river (Fig. 5a; XBGMR, 1978, 1993). No décollement structure has been observed between the basement top and the sedimentary cover. Besides, a southward backthrust of basement rocks above sediments can be observed to the south of the section, but the net slip must be limited as it rapidly dies out, the fault laterally evolving to a fold toward the west (Fig. 5a). Unconformity of the basal contact of Mesozoic sediments on top of basement units is observed in the southernmost part of the section (Figs. 5a and 6a). As a whole, the successive sub-horizontal and monocline segments define a hinge fold at regional scale (Fig. 5b). Nevertheless, while $~ 900 \mathrm{~m}$ thick of Triassic sediments have been drilled along the W1 well in the basin (Fig. 5b), no Triassic series have been observed further south in the range, in the section area (Fig. 5a). Indeed, Lowermost to Middle Jurassic levels have been observed and mapped directly on top of the basement units (Fig. 5a; XBGMR, 1978, 1993). Similarly to the Houxia area, basal contact of the Mesozoic series suggests its onlap deposit, from basin to range, at least during Triassic and Lower-Middle Jurassic.

More local-scale evidences for onlap sedimentation can also be observed in the Hutubi He area. First, to the south end of the section, Lower Jurassic strata display a kilometer scale onlap type structure on top of basement units, i.e. with younger sediments progressively 
covering basement, from north to south (Figs. 5a and 6a). Second, $\sim 10 \mathrm{~km}$ west of the Hutubi River, subhorizontal layers of the Lower Jurassic formation, which can be continuously followed in few kilometers in this small valley, structurally onlap on the deformed Paleozoic basement units (Fig. 6b). There, stratification planes are markedly oblique with the top of the Paleozoic units and no deformation has been observed along this contact. In the landscape, younger Jurassic sediments progressively extend to the south, on top of the Carboniferous units. Sediments progressively overlie and cover a $\sim 150 \mathrm{~m}$ high step of the basement top which implies that a significant relief existed during Jurassic sediments deposition.

To the north of the Wusu section, first-order structure of the Mesozoic-Cenozoic series displays a $40-45^{\circ}$ north dipping monocline (Figs. $7 \mathrm{a}$ and $7 \mathrm{~b}$ ). To the south, bedding is subhorizontal and structure of the sedimentary series is marked by a large hinge fold. As drawn on the geological map, thrust faults are observed at the surface, but seismic data show that they do not extend downward into the Mesozoic series (Fig. 7b; suppl. material), which is compatible with the limited throw produced by these faults as deduced from map data analysis (Fig. 7a). While $400 \mathrm{~m}$ of Triassic sediments have been found in a drilled well in the basin, close to this section (see W2 on Fig. 7a), Triassic series becomes much thinner to the south and Jurassic sandstones, sometimes, directly lie on top of the Carboniferous rocks with an erosional undeformed contact (Fig. 7c; XBGMR, 1973).

\section{Discussion and conclusions}

In parallel to rather classical view of frontal thrust systems, this study highlights that the northern piedmont of Tian Shan also displays segments where Mesozoic series are preserved unconformably onto the basement with onlap-type relationships. Such features are pointed out along two distant cross-sections and have also been clearly shown at outcrop-scale. Sedimentary breccias, showing very limited transport distances, have been found within 
Lower Jurassic sediments of the internal parts of the range. Whatever the scale, all these observations clearly show the existence of proximal relief when Triassic/Jurassic sediments were deposited. Our field observations are consistent with previously published sedimentological data - paleocurrent measurements, heavy mineral composition, sedimentological source analyses - in the Junggar and Tarim basins which suggest that Tian Shan could already have existed as a "positive" geomorphologic feature during Mesozoic times (Hendrix et al., 1992, Graham et al., 1993; Hendrix, 2000; Li et al., 2004).

In the field, the local-scale observation of onlap sedimentary architecture reveals that the paleo-altitude difference can reach $100-150 \mathrm{~m}$ in a hectometer horizontal distance, which highlights local steep slopes (cf. Fig. 6b). Together with the sedimentological observations in the Houxia valley, this suggests that small-scale ridges with intercalated intra-mountainous basins have probably existed during Mesozoic (Fig. 8a).

Drill wells W1 and W1' (Figs. 4a and 4b) display $\sim 1200 \mathrm{~m}$ of Lower Jurassic sediments (e.g. Badaowan and Shangonghe Fm., Fig. 2). A comparable thickness for Lower Jurassic has also been observed in the Manas area, $50 \mathrm{~km}$ west of the Hutubi section (Fig. 2; Hendrix et al., 1992). Following the geological maps (XBGMR; 1978, 1993), Middle Jurassic series directly lie unconformably onto the Carboniferous basement, without Triassic and Lower Jurassic sediments in the southern part of the Hutubi River (see location A in Fig. 4a). The thickness difference of Jurassic sediments reaches $\sim 1200 \mathrm{~m}$ between the location $\mathrm{A}$ and the drill well location, for a horizontal distance of about $50 \mathrm{~km}$ (Fig. 4a). Such thickness difference may result from subsidence mechanisms. However, whatever the scale considered in this study, Triassic and mostly Jurassic series, up to the late Jurassic Kalaza formation deposit, display parallel bedding with no growth strata observed (Figs. $5 b, 6$ and 7b). Such feature shows that, at the scale of the studied area, significant vertical differential movements may have hardly occurred during Triassic to Upper Jurassic sedimentation. In addition, as 
described above, Jurassic strata often overlie directly on Carboniferous by onlap, without fault or syn-sedimentary deformations. Seismic profiles across the southern margin of the Junggar basin do not display major fault that could have controlled sedimentation for the Early Jurassic period (Allen et al., 1991; Wang et al., 2005). No evidence for structural control on local subsidence could thus be argued here. At larger scale, flexure - either thermal or tectonic - could also have controlled the subsidence for Mesozoic series accumulation.

If considering thermal control, the latest regional tectono-magmatic event occurring before Mesozoic in the Central Tian Shan area ended during early Permian (see compilation by Han et al., 1999), which is about 100 Ma earlier than Jurassic sedimentation. Therefore, according to Hendrix et al. (1992), it seems that thermal driving mechanism may only play a weak role for the Early and Middle Jurassic sedimentation. If considering tectonic control, compressional flexure may also be hard to explain as, for comparable vertical differential movements, buckling of a stable continental lithosphere would result in much larger wavelength $(200-300 \mathrm{~km})$ than observed in this study $(\sim 50 \mathrm{~km})$ as shown by mechanical modelling (Martinod and Davy, 1992, 1994; Burov et al., 1993; Cloetingh et al., 1999).

At the scale of the present study, Jurassic sedimentation seems hardly controlled by either tectonic or thermal subsidence across northern Tian Shan. Accordingly, the 1200$1300 \mathrm{~m}$ thickness difference may be mainly produced by infilling of a long-lasting remnant relief of, at least, 1200-1300 m high at that period (i.e. from Triassic/Lowermost Jurassic; Fig. 8a). During Middle Jurassic, finer-grained sediments were conformably deposited on top of the Lower Jurassic strata within the basin, and were deposited onlap on the Paleozoic basement toward the range (Figs. 5a and 8b). Middle Jurassic sediments of the Xishanyao and Toutunhe formations extend to a larger area with respect to the Lower Jurassic and, as a whole, the paleorelief lateral extension was certainly less important during Middle Jurassic than during Triassic/Early Jurassic (Fig. 8b). During latest Jurassic to Early Cretaceous, thick 
breccias were deposited onto the Middle Jurassic sediments through an angular unconformity (cf. Kalaza Fm.). These breccias are restricted to the front of the modern Tian Shan and change rapidly to finer-grained deposits in lateral equivalents. This configuration is reminiscent of the general architecture of current fans deposited along the modern Tian Shan range that originate from the present day high relief to the south, but show limited northward transport of sediments (Fig. 8c). In turn, location of the main morphological northern front of the paleo- Tian Shan, during Latest Jurassic to Early Cretaceous, would approximately coincide with the one of the current range front (Fig. 5). The uplift documented by these coarse-grained sedimentary breccias is also recorded by AFT chronology studies; Fissiontrack modeling indicates a ca. 160 and 120 Ma cooling age along a Dushanzi-Kuqa corridor, in the mountain interior (Dumitru et al., 2001; Jolivet et al., 2010). Apatite sampled from Bayanbulak area yields the earliest cooling ages of Early Cretaceous (Dumitru et al., 2001; Wang et al. 2009).

Because no major tectonic event occurred in the Northern Tian Shan during Mesozoic times (e.g. De Grave et al., 2007), the Paleozoic subduction-collision orogeny (Gao et al., 1998; Laurent-Charvet et al., 2002; Charvet et al., 2007) appears as the most probable origin of the Mesozoic paleorelief above described. In such case, the Tian Shan would persist as remnant relieves for several tens of $\mathrm{Ma}$ after the end of the orogenic events which are progressively and unconformably overlain by Triassic and then Jurassic sedimentation (e.g. onlap structures, mesoscale paleorelief infilling). This scenario implies extremely low erosion rates to allow the preservation of a significant relief; such feature has already been reported for other regions of Central Asia from thermochronological (AFT) and field data analyses (Jolivet et al., 2007). In parallel, Central Asia Mesozoic tectonic history is marked by the polyphased Cimmerian orogeny in Tibet area (e.g. Hendrix et al., 1992; Sobel and Dumitru, 1997; De Grave et al., 2007). Low amplitude, far-field effects can thus be recognized in the 
Mesozoic northern Tian Shan: one early collision stage - Qiantang/Kunlun blocks during Late

245 Triassic/Middle Jurassic - would correspond to the drastic coarsening of the Lower Jurassic sedimentation. In turn, a later collision stage - Lhasa/Qiantang blocks during Late Jurassic/Early Cretaceous - well corresponds to the deposits of the thick and coarse breccias of the Kalaza Fm. at that time. In this case, a tectonic origin of the relief rejuvenation is attested by a major angular unconformity observed regionally.

As unambiguously demonstrated, the physiography of the modern Tian Shan dominantly results from the recent tectonic evolution of the area (e.g. Tapponnier and Molnar, 1977; Avouac et al., 1993; Métivier and Gaudemer, 1997; Charreau et al., 2009). However, this study put forward that the current Tian Shan topography can probably not be considered as the consequence of the Cenozoic intracontinental reactivation alone, but as a combination of the Cenozoic deformations superimposed on a reminiscent Mesozoic paleo-range. These new results question on the amplitude of the movements that could be estimated along the northern front structures during Cenozoic intracontinental reactivation.

\section{Acknowledgements}

259 Field and laboratory work in the present study are financially supported by Chinese National 973 Program (2009CB825008) and Chinese National S\&T Major Project 2011ZX05008.

Prof. A.R. Caroll, Dr. J. Charreau, and an anonymous reviewer are warmly thanked for their

262 constructive reviews. We are also grateful for the help by Prof. Carlo Doglioni (Editor) and Prof. Gerhard Wörner (Associate Editor). Discussions on seismic profiles' interpretation with scholarship from French Embassy in Beijing and IGGCAS. 


\section{References}

267

268

269

270

271

272

273

274

275

276

277

278

279

280

281

282

283

284

285

Abdrakhmatov, K.Y., Aldazhanov, S.A., Hager, B.H., Hamburger, M.W., Herring, T.A., Kalabaev, K.B., Makarov, V.I., Molnar, P., Panasyuk, S.V., Prilepin, M.T., Reilinger, R.E., Sadybakasov, I.S., Souter, B.J., Trapeznikov, Y.A., Tsurkov, V.Y. and Zubovich, A.V., 1996. Relatively recent construction of the Tien Shan inferred from GPS measurements of presentday crustal deformation rates. Nature, 384, 450-453.

Allen, M.B., Windley, B.F., Zhang, C., Zhao, Z.Y. and Wang, G.R., 1991. Basin Evolution within and Adjacent to the Tien-Shan Range, NW China. J. Geol. Soc. London, 148, 369-378.

Avouac, J.P., Tapponnier, P., Bai, M., You, H. and Wang, G., 1993. Active Thrusting and Folding Along the Northern Tien-Shan and Late Cenozoic Rotation of the Tarim Relative to Dzungaria and Kazakhstan. J. Geophys. Res., 98, 6755-6804.

Burchfiel, B.C., Brown, E.T., Deng, Q.D., Feng, X.Y., Li, J., Molnar, P., Shi, J.B., Wu, Z.M. and You, H.C., 1999. Crustal shortening on the margins of the Tien Shan, Xinjiang, China. Int. Geol. Rev., 41, 665-700.

Burov, E.B., Lobkovsky, L.I., Cloetingh, S. and Nikishin, A.M., 1993. Continental lithosphere folding in Central Asia (Part II): constraints from gravity and topography. Tectonophysics, 226, 73-87.

Carroll, A.R., Liang, Y., Graham, S.A., Xiao, X., Hendrix, M.S., Chu, J., and McKnight, C.L., 1990. Junggar basin, northwest China: Trapped late Paleozoic ocean. Tectonophysics, 181, 114. 
286 Carroll, A. R., Graham, S.A., Hendrix, M.S., Ying, D., and Zhou, D., 1995. Late Paleozoic 287 tectonic amalgamation of northwestern China: sedimentary record of the northern Tarim, 288 northwestern Turpan, and southern Junggar basins. Geol. Soc. Am. Bull., 107, 571-594.

Carroll, A.R., Graham, S.A. and Smith, M.E., 2010. Walled sedimentary basins of China. 290 Basin Res., 22, 17-32.

Charreau, J., Chen, Y., Gilder, S., Barrier, L., Dominguez, S., Augier, R., Sen, S., Avouac, 292 J.P., Gallaud, A., Graveleau, F. and Wang, Q.C., 2009. Neogene uplift of the Tian Shan 293 Mountains observed in the magnetic record of the Jingou River section (northwest China). Tectonics, 28, TC2008, doi:10.1029/2007TC002137.

Charvet, J., Shu, L.S. and Laurent-Charvet, S., 2007. Paleozoic structural and geodynamic 296 evolution of eastern Tianshan (NW China): welding of the Tarim and Junggar plates. Episodes, 30, 162-186.

Cloetingh, S., Burov, E. and Poliakov, A., 1999. Lithosphere folding: primary response to 299 compression? (from central Asia to Paris basin). Tectonics, 18, 1064-1083.

De Grave, J., Buslov, M.M. and Van den Haute, P., 2007. Distant effects of India-Eurasia 301 convergence and Mesozoic intracontinental deformation in Central Asia: Constraints from 302 apatite fission-track thermochronology. J. Asian Earth Sc., 29, 188-204. Geophys. Res., 101, 5895-5920. 
Mesozoic tectonic evolution of central Asia: From continental assembly to intracontinental deformation (Hendrix, M.S., and Davis,G.A., eds). Geol. Soc. Am. Mem., 194, 71-99.

Gao, J., Li, M.S., Xiao, X.C., Tang, Y.Q. and He, G.Q., 1998. Paleozoic tectonic evolution of the Tianshan Orogen, northwestern China. Tectonophysics, 287, 213-231.

Graham, S.A., Hendrix, M.S., Wang, L.B. and Carroll, A.R., 1993. Collisional successor basins of western China Impact of tectonic inheritance on sand composition. Geol. Soc. Am. Bull., 105, 323-344.

Han B.F., He, G.Q. and Wang, S., 1999. Postcollisional mantle-derived magmatism, underplating and implications for basement of the Junggar Basin. Sci. China. Ser. D, 42, 113119.

Hendrix, M.S., Graham, S.A., Carroll, A.R., Sobel, E.R., Mcknight, C.L., Schulein, B.J., and Wang, Z.X., 1992. Sedimentary Record and Climatic Implications of Recurrent Deformation in the Tian-Shan - Evidence from Mesozoic Strata of the North Tarim, South Junggar, and Turpan Basins, Northwest China. Geol. Soc. Am. Bull., 104, 53-79.

Hendrix, M.S., Dumitru, T.A. and Graham, S.A., 1994. Late Oligocene Early Miocene Unroofing in the Chinese Tien-Shan - an Early Effect of the India-Asia Collision. Geology, 22, 487-490.

Hendrix, M.S., 2000. Evolution of mesozoic sandstone compositions, southern Junggar, northern Tarim, and western Turpan basins, northwest China: A detrital record of the ancestral Tian Shan. J. Sed. Res., 70, 520-532.

Huang, B. and Li, J., 2007. Sporopollen assemblages from the Xishanyao and Toutunhe formations at the Honggou section of the manasi river, xinjiang and their stratigraphical significance. Acta Micropaleontologica Sinica, 24, 170-193. 
331 Jolivet, M., Ritz, J.F., Vassalo, R., Larroque, C., Braucher, R., Todbileg, M., Chauvet, A., Sue,

332 C., Arnaud, N., de Vicente, R., Arzhanikova, A. and Arzhanikova, S., 2007. Mongolian 333 summits: An uplifted, flat, old but still preserved erosion surface. Geology, 35, 871-874.

334 Jolivet, M., Dominguez J., Charreau J., Chen, Y., Farley, K.A., Li, Y.A. and Wang, Q.C., 335 2010. Mesozoic and Cenozoic tectonic history of the Central Chinese Tian Shan: Reactivated 336 tectonic structures and active deformation. Tectonics, 29, TC6019, 337 doi:10.1029/2010TC002712.

Laurent-Charvet S., Charvet, J., Shu, L.S., Ma, R.S. and Lu, H.F., 2002. Late Paleozoic collisional strike-slip deformations in Tianshan and Altay, eastern Xinjiang, NW China. Terra Nova, 14, 249-256.

Li Z., Zhang L., Qian C., Wang Y. and Bai G., 1978. Regional geological survey report of

Geological map 1:200000, Shichang sheet. China Ministry of Geology and Mineral Resource, 343 Beijing.

Li, Z., Song, W.J., Peng, S.T., Wang, D.X. and Zhang, Z.P., 2004. Mesozoic-Cenozoic tectonic relationships between the Kuqa subbasin and Tian Shan, northwest China: constraints from depositional records. Sed. Geol., 172, 223-249.

Liu, Z., 1990. Sporo-pollen assemblage from Middle Jurassic Xishanyao Formation of 348 Shawan, Xinjiang, China. Acta Palaeontologica Sinica, 29, 63-82. 28. 
352 Martinod, J., and Davy, P., 1992. Periodic instabilities during compression of the lithosphere

353 1. Deformation modes from an analytical perturbation method. J. Geophys. Res., 92, 19993542014.

355 Martinod, J. and Davy, P., 1994. Periodic instabilities during compression of the lithosphere 2. 356 Analogue experiments. J. Geophys. Res., 99, 12057-12069.

357 Métivier, F. and Gaudemer, Y., 1997. Mass transfer between eastern Tien Shan and adjacent 358 basins (central Asia): Constraints on regional tectonics and topography. Geophys. J. Int., 128, $359 \quad 1-17$.

Sengör, A.M.C., Natal'in, B.A., Burtman, V.S., 1993. Evolution of the Altaid tectonic collage and Paleozoic crust growth in Eurasia. Nature, 364, 299-307.

Sobel, E.R. and Dumitru, T.A., 1997. Thrusting and exhumation around the margins of the western Tarim basin during the India-Asia collision. J. Geophys. Res., 102, 5043-5063.

Tapponnier, P. and Molnar, P., 1977. Active Faulting and Tectonics in China. J. Geophys. Res., 82, 2905-2930.

Wang, B. Chen, Y., Zhan, S., Shu, L.S., Faure, M., Cluzel, D., Charvet, J. and LaurentCharvet, S., 2007. Primary Carboniferous and Permian paleomagnetic results from the Yili Block (NW China) and their implications on the geodynamic evolution of Chinese Tian Shan Belt. Earth Planet. Sci. Lett., 263, 288-308.

370 Wang, Q. C., Li S. J. and Du z. L., 2009. Differential uplift of the Chinese Tian Shan since the 371 Cretaceous: constraints from sedimentary petrography and apatite fission-track dating. Int. J. 372 Earth Sci., 98, 1341-1363. 
373 Wang, X.W., Wang, X.W., Liu, J.P., Liu, J.P. and Ma, Y.S., 2005. Analysis of the fold-thrust 374 zone in the southern Junggar Basin, north western China. Earth Science Frontiers, 12, 411375421.

376 Wang, Z., Wu, J., Lu, X., Liu, C., and Zhang, J., 1990, Polycyclic tectonic evolution and 377 metallogeny of the Tian Shan mountains. Beijing, Science Press.

378 Windley, B.F., Allen, M.B., Zhang, C., Zhang, C., Zhao, Z.Y. and Wang, G.R., 1990.

379 Paleozoic accretion and Cenozoic redeformation of the Chinese Tien Shan range, Central Asia. 380 Geology, 18, 128-131.

XBGMR-WUSU, 1973, Bureau of Geological and Mineral Resources of Xinjiang Uygur 382 Autonomous Region, Geological map of Wusu Region, Scale 1:200.000, China Ministry of Geology and Mineral Resource, Beijing.

XBGMR-HOUXIA, 1977, Bureau of Geological and Mineral Resources of Xinjiang Uygur Autonomous Region, Geological map of Houxia Region, Scale 1:200.000, China Ministry of Geology and Mineral Resource, Beijing.

XBGMR-SHICHANG, 1978, Bureau of Geological and Mineral Resources of Xinjiang Ministry of Geology and Mineral Resource, Beijing.

XBGMR, 1993, Regional geology of Xinjiang Uygur autonomy region.- Geological Memoirs, Junggar Basin, Xinjiang, and their stratigraphic significance. Acta Geologica Sinica, 4, 375379. 
395 Yang, J.L, Wang Q.F. and Lu H.N., 2005, Discovery of cretaceous and Paleocene charophyte

396 floras from well $\mathrm{Hu}-2$ in the southern edge of Junggar basin. Acta Micropalaeontologica 397 Sinica, 22, 251-268. 


\section{Figure captions}

399 Fig. 1 Simplified geological map of the northern Tian Shan from Wusu to Urumqi areas.

Mesozoic is most exposed in the southernmost parts of the Junggar basin along the adjacent

Tian Shan range, particularly to the East (Urumqi area). 'He' indicates river in Chinese (modified after XBGMR, 1993).

403

404

405

406

407

408

409

410

411

412

413

414

Fig. 2 Synthetic and representative stratigraphic log made in the Manasi He area, northern Tian Shan piedmont, where Cenozoic have been widely eroded (modified after Hendrix et al., 1992).

Fig. 3 Landscape pictures of representative features of the Mesozoic sedimentary series (see locations on Fig.1) (a) Coarse-grained conglomerate of lowermost Jurassic forming prominent bars in the landscape (southern Qingshui He area); (b) Uppermost Jurassic coarse-grained breccias (Kalaza Fm. - $\left.\mathbf{J}_{3 \mathrm{k}}\right)$ unconformably overlying the Upper Jurassic Qigu formation $\left(\mathrm{J}_{3 \mathrm{q}}\right.$; Hutubi He area); (c) Close-up view of the Uppermost Jurassic Kalaza Fm. breccias (west to Hutubi He area). Note the angular shape of the clasts (locally exceeding $50 \mathrm{~cm}$ ) and the clastsupported character of the coarser levels.

Fig. 4 Structural and sedimentological observations in the Houxia area. (a) Simplified geological map with some field structural measurements (modified after XBGMR, 1977), (b) detailed geological cross-section across the northern limb of the syncline structure (see location on Fig. 4a), (c) Close-up view of the Lower Jurassic breccias including Carboniferous basement angular clasts (see location on Fig. 4b), (d) picture of the steep bedding of Jurassic layers close to the southward thrust (see location on Fig. 4b).

Fig. 5 (a) Simplified geological map of the Hutubi He area (modified after XBGMR, 1978, 1993) with few structural measurements from field work. 'A' indicates location where Middle 
Jurassic deposits directly and unconformity lie onto Carboniferous basement without Triassic or Lower Jurassic, (b) Geological cross-section along the Hutubi He constrained by field data, seismic profile (after Wang et al., 2005) and nearby drill wells W1 and W1'. Location of the section is indicated on Fig. 5a. Extension of the available seismic profile is indicated on the section.

Fig. 6 Examples of onlap structures of the Jurassic sediments over the Paleozoic basement units. (a) Picture and interpretation field sketch of the southern part of the Hutubi He (see location on Fig. 5a): note the overall southward onlap of the Jurassic sediments over the folded basement. To the north, a basement block is back thrusted over the sediments (see Fig. 5b), (b) Picture and interpretation field sketch of a small valley, west of the Hutubi $\mathrm{He}$ (see location on Fig. 5a): meso-scale basement relief covered by Jurassic sandstones as evidenced by onlaps over a steep inherited $\sim 150$ m high basement paleorelief (scarp). Basement rocks are deformed with a large inclined Paleozoic fold.

Fig. 7 Structural and sedimentological observations in the Wusu area. (a) Simplified geological map (modified after XBGMR, 1973) with few structural measurements. (b) Geological cross-section constrained by field data, seismic profile and drill well W2 (see Fig. 7a for location). (c) Picture and corresponding field sketch interpretation of the unconformable contact between Jurassic layers and the Carboniferous basement (see Fig. 7a for location).

Fig. 8 Sketch views of the paleogeographic evolution of the northern piedmont of Tian Shan during Early, Middle and Upper Jurassic/Cretaceous boundary. Main observations that constrain this study are localized on the drawings as: A for Fig. 3a; B for Fig. 4c (lower Jurassic sedimentary breccias); C for Fig. 6a (onlap covering of Paleozoic basement rocks by 
444 Jurassic sandstones) and D for Figs. 3b and 3c (thick Kalaza Fm. breccias with angular 445 discordance at the base). 


\section{The Mesozoic paleorelief of the northern Tian Shan (China)}

2

3

4

5

6

7

8

9

10

11

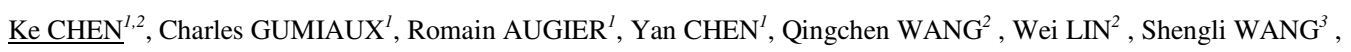

1. Institut des Sciences de la Terre d'Orléans (ISTO), Université d'Orléans, CNRS: UMR6113, Université François Rabelais - Tours, - INSU,

Campus Géosciences, 1A rue de la Férollerie, 45071 Orléans cedex 2, France

2. State Key Laboratory of Lithospheric Evolution, Institute of Geology and Geophysics, Chinese Academy of Sciences, P.O. 9825, Beijing 100029, China

3. Department of Earth Sciences, Nanjing University, 210093, Nanjing, China

\section{Abstract}

The Tian Shan range offers a natural laboratory to study orogenic processes. Most of the previous studies focused on either the Paleozoic evolution of the range or its Cenozoic intracontinental evolution linked with the India-Asia collision. In this study, detailed field investigations on the relationship between sedimentary cover and basement constrain the Mesozoic evolution of the northern Tian Shan. Sedimentological observations argue for limited transport distance for Lower and Uppermost Jurassic deposits. Geological sections presented in this paper show that, in preserved locations, Triassic to Jurassic sedimentary series present a continuous onlap type sedimentary unconformity on the top of the basement. At different scales, observations clearly evidence the existence of a major paleorelief during Mesozoic. According to the present study, the current Tian Shan range topography and the associated movements along its northern front structures cannot be considered as the consequence of Cenozoic reactivation alone.

\section{Keywords}

Tian Shan, paleorelief, Mesozoic, regional onlap, reactivation, India-Asia collision. 


\section{Introduction}

The modern Tian Shan is one of the major mountain ranges in Central Asia. The current structure of Tian Shan mainly results from a combination of two main tectonic events: i) subductions, arc-accretions and continental collision during Paleozoic (e.g. Carroll et al., 1990; Wang et al., 1990; Windley et al., 1990; Sengör et al. 1993; Carroll et al., 1995; Gao et al., 1998; Laurent-Charvet et al., 2002; Charvet et al., 2007; Wang et al., 2007) and ii) intracontinental reactivation linked to the India-Asia collision, during Cenozoic (e.g. Tapponnier and Molnar, 1977; Avouac et al., 1993). At first order, the modern Tian Shan corresponds to a raised east-west trending Paleozoic 'basement' range, flanked by two closed intracontinental basins whose infill is a particularly accurate record for both tectonic and climate evolutions (Fig. 1). The present-day high topography of Tian Shan, with a mean altitude of $\sim 2500 \mathrm{~m}$ and summits of more than $7000 \mathrm{~m}$, is traditionally related to the latest intracontinental deformation of the range (e.g. Tapponnier and Molnar, 1977; Avouac et al., 1993; Burchfiel et al., 1999). Age constraints for the onset of this intracontinental reactivation range from 10 to 24 Ma (e.g. Avouac et al., 1993; Hendrix et al., 1994; Abdrakhmatov et al., 1996; Métivier and Gaudemer, 1997; Sobel et al., 1997; Dumitru et al., 2001; Charreau et al., 2009). In spite of relative age discrepancies (mostly related to the method applied), all ages estimated for the deformation and the associated relief erosion suggest that the mountain range reactivation and relief creation began during Early Miocene at oldest.

However, recent Fission-track analyses suggest that uplifting may have existed well before the onset of the Tertiary reactivation through Tian Shan, with exhumation ages such as 160-120 Ma in central Tian Shan, 200-250 Ma detritus cooling age in the Manas River valley (Dumitru et al., 2001; Jolivet et al., 2010) or 140-120 Ma from Bayanbulak intracontinental basin, in the southern Tian Shan (Wang et al., 2009). Moreover, Triassic to Cretaceous sediments are composed of thick continental series characterized by massive coarse-grained 
formations within both basins, suggesting rather high erosion rate at that time (Hendrix, 2000; Carroll et al., 2010).

This study considers the Mesozoic tectonic and morphologic evolution of Tian Shan through field structural and sedimentological analyses of Mesozoic deposits. It focuses on the northern piedmont of the range, along a $\sim 280 \mathrm{~km}$ west-east trending segment (Fig. 1). Thanks to deep incisions of seasonal rivers, contacts between Paleozoic basement and MesozoicCenozoic sedimentary cover are particularly well exposed along several north-south trending sections in this region (Fig. 1). Such new constraints on Mesozoic evolution of the Tian Shan area would lead to reconsider the contribution of Cenozoic tectonics in the modern mountain range building as well as to better quantify the net shortening amount during that period.

\section{Stratigraphy of the Mesozoic sediments within the study area}

Sedimentary series can be extensively observed and have already been studied within the Junggar basin, as summarized below (Figs. 1 and 2; Hendrix et al., 1992 and references therein; XBGMR, 1993). Basement units of the north Tian Shan mainly consist of Paleozoic volcanic and sedimentary rocks. From bottom to top, the entire Mesozoic series is composed of $\sim 5 \mathrm{~km}$ thick continental clastic deposits highlighting high sedimentation/preservation rates (Fig. 2). Thanks to numerous studies aimed at oil and gas exploration and to 1:200.000 mapping projects hold in this area, ages of the Mesozoic sequences were mainly constrained by floral and sporopollen assemblage analyses (Li et al., 1978; Yang et al., 1982; Liu, 1990; XBGMR, 1993; Lu and Deng, 2005; Yang et al., 2005; Huang and Li, 2007). In the study area, the Triassic series are mostly missing along the piedmont though locally exposed (Fig. 1). Where it crops out, Triassic displays alluvial sandstones and conglomerates intercalated within and silty mudstones (red-beds). At the scale of the northern Tian Shan piedmont, Lowermost Jurassic layers indicate a change in the sedimentation as they consist in thick and 
coarse conglomeratic deposits, as exposed in the south of Qingshui He (Fig. 3a). Thickness of Lower Jurassic reaches $1000 \mathrm{~m}$ over the area extending from Manasi to Urumqi, and decreases westwardly and eastwardly. Sediments become progressively finer upward, grading into $\sim 3 \mathrm{~km}$ thick series of Lower/Middle Jurassic gray sandstones, silty shales (Fig. 2). Middle Jurassic sandstones and mudstones locally contain coal-rich layers consistent with a lacustrine depositional facies (Hendrix et al., 1992). Upper Jurassic comprises typical finegrained red beds where conglomerates remain scarce. The transition from Jurassic to Cretaceous series is marked by up to $800 \mathrm{~m}$ thick sedimentary breccias (Kalaza formation J3k; Fig. 3b) made of coarse-grained angular clasts (Fig. 3c). It rapidly dies laterally and grades to sandstones within the Junggar basin itself (XBGMR, 1978; 1993). The marked unconformity between the Kalaza formation and the underlying finer-grained Upper Jurassic red beds (Fig. 3b) suggests a short transport distance of material before deposition and nearby relief uplifting.

In this study, Mesozoic sediments have also been extensively observed within internal parts of the range, and more particularly in the eastern part of the studied area (Fig. 1). Triassic to Jurassic sediments are encountered on top of the Paleozoic basement units, at rather high altitudes (2000 to $3000 \mathrm{~m}$ ) in comparison with the mean altitude of the foreland fold-and-thrust belts (1000 to $1500 \mathrm{~m}$ high). In the Houxia valley for instance - $65 \mathrm{~km}$ SSW of Urumqi - a Lower to Upper Jurassic continuous sedimentary series is preserved in a syncline structure (Fig. 4a). According to the geological map (Fig. 4a; XBGMR, 1977), Lower Jurassic formations - i.e. Shangonghe Fm. to the northwest and Lowermost Jurassic Badaowan Fm. to the east - directly overlie on top of Carboniferous basement units, without intercalated Triassic sediments. Besides, south and north verging thrusts developed along parts of the northern and southern limbs of the fold, respectively (Fig. 4a). A section made across the north limb of the syncline displays continuous Lower to Middle Jurassic series with 
no fault contact observed (Fig. 4b). From south to north, bedding planes progressively straighten up from $\sim 30^{\circ}$ south dipping to vertical, and even overturned just below the south verging thrust (Figs. $4 \mathrm{a}, 4 \mathrm{~b}$ and $4 \mathrm{~d}$ ). From a sedimentological point of view, the upper and main part of Jurassic series is made of fine-grained sandstones and mudstones while the lowermost deposits of the series is characterized by intercalations of coarse-grained sedimentary breccias mostly made of highly angular clasts of Carboniferous tuffaceous sandstones (Fig. 4c). Local abundance of these breccias and the common lithological nature of the clasts with the adjacent basement unit strongly suggest a very short transport distance.

\section{Structural analysis of the Mesozoic basal contact}

Deformation of the northern Tian Shan has already been studied through the structural analysis of sedimentary series, within the Cenozoic foreland basin (e.g. Avouac et al., 1993; Deng et al., 1996; Burchfiel et al., 1999). This part focuses on the basal contact of the Mesozoic sediments, in the northern "front" area of Tian Shan.

As shown on the map (Fig. 1), some parts of the piedmont display northward thrusts that mark out the boundary in between the Paleozoic uplifted basement units and relatively subsiding proximal foreland basin. Yet, as described above, Mesozoic series are not solely restricted to the piedmont fold-and-thrust belts but are also well preserved on top of the basement units, within the range (Fig. 1). Then, some other segments of the piedmont display perfectly continuous Mesozoic sedimentary series from basin until internal and higher parts of the range, without being strained by any faulting or folding in the range front area (Fig. 1). Structural analysis of such unstrained basal contact of Mesozoic series is presented for two of the sections constructed from field work combined with available seismic profiles and drillholes data: the Hutubi He and the Wusu sections (Fig. 1). 
At first order, to the north of the Hutubi He area, Triassic to Neogene sedimentary

121 series form a rather simple monocline structure, dipping $15-20^{\circ}$ to the north (Fig. 5a). The southernmost fold-and-thrust belt is composed of one gentle upright anticline and associated syncline with only very limited thrusts developed along the hinge of the fold (Fig. 5a). This belt can be regarded as a fault-propagation fold structure according to the available seismic profile (Wang et al., 2005; Fig. 5b). Further south, entering within the interior parts of the range, sub-horizontal Lower Jurassic strata lie on top of the Carboniferous units (Fig. 5b). While basement is strongly deformed, as evidenced by sub-vertical cleavage, its sedimentary cover is only gently folded as illustrated on the geological map, few kilometers west of the river (Fig. 5a; XBGMR, 1978, 1993). No décollement structure has been observed between the basement top and the sedimentary cover. Besides, a southward backthrust of basement rocks above sediments can be observed to the south of the section, but the net slip must be limited as it rapidly dies out, the fault laterally evolving to a fold toward the west (Fig. 5a). Unconformity of the basal contact of Mesozoic sediments on top of basement units is observed in the southernmost part of the section (Figs. 5a and 6a). As a whole, the successive sub-horizontal and monocline segments define a hinge fold at regional scale (Fig. 5b). Nevertheless, while $900 \mathrm{~m}$ thick of Triassic sediments have been drilled along the W1 well in the basin (Fig. 5b), no Triassic series have been observed further south in the range, in the section area (Fig. 5a). Indeed, Lowermost to Middle Jurassic levels have been observed and mapped directly on top of the basement units (Fig. 5a; XBGMR, 1978, 1993). Similarly to the Houxia area, basal contact of the Mesozoic series suggests its onlap deposit, from basin to range, at least during Triassic and Lower-Middle Jurassic.

More local-scale evidences for onlap sedimentation can also be observed in the Hutubi He area. First, to the south end of the section, Lower Jurassic strata display a kilometer scale onlap type structure on top of basement units, i.e. with younger sediments progressively 
covering basement, from north to south (Figs. 5a and 6a). Second, $10 \mathrm{~km}$ west of the Hutubi River, subhorizontal layers of the Lower Jurassic formation, which can be continuously followed in few kilometers in this small valley, structurally onlap on the deformed Paleozoic basement units (Fig. 6b). There, stratification planes are markedly oblique with the top of the Paleozoic units and no deformation has been observed along this contact. In the landscape, younger Jurassic sediments progressively extend to the south, on top of the Carboniferous units. Sediments progressively overlie and cover a $\sim 150 \mathrm{~m}$ high step of the basement top which implies that a significant relief existed during Jurassic sediments deposition.

To the north of the Wusu section, first-order structure of the Mesozoic-Cenozoic series displays a $40-45^{\circ}$ north dipping monocline (Figs. 7a and $7 \mathrm{~b}$ ). To the south, bedding is subhorizontal and structure of the sedimentary series is marked by a large hinge fold. As drawn on the geological map, thrust faults are observed at the surface, but seismic data show that they do not extend downward into the Mesozoic series (Fig. 7b; suppl. material), which is compatible with the limited throw produced by these faults as deduced from map data analysis (Fig. 7a). While $400 \mathrm{~m}$ of Triassic sediments have been found in a drilled well in the basin, close to this section (see W2 on Fig. 7a), Triassic series becomes much thinner to the south and Jurassic sandstones, sometimes, directly lie on top of the Carboniferous rocks with an erosional undeformed contact (Fig. 7c; XBGMR, 1973).

\section{Discussion and conclusions}

In parallel to rather classical view of frontal thrust systems, this study highlights that the northern piedmont of Tian Shan also displays segments where Mesozoic series are preserved unconformably onto the basement with onlap-type relationships. Such features are pointed out along two distant cross-sections and have also been clearly shown at outcrop-scale. Sedimentary breccias, showing very limited transport distances, have been found within 
Lower Jurassic sediments of the internal parts of the range. Whatever the scale, all these observations clearly show the existence of proximal relief when Triassic/Jurassic sediments were deposited. Our field observations are consistent with previously published sedimentological data - paleocurrent measurements, heavy mineral composition, sedimentological source analyses - in the Junggar and Tarim basins which suggest that Tian Shan could already have existed as a "positive" geomorphologic feature during Mesozoic times (Hendrix et al., 1992, Graham et al., 1993; Hendrix, 2000; Li et al., 2004).

In the field, the local-scale observation of onlap sedimentary architecture reveals that the paleo-altitude difference can reach $100-150 \mathrm{~m}$ in a hectometer horizontal distance, which highlights local steep slopes (cf. Fig. 6b). Together with the sedimentological observations in the Houxia valley, this suggests that small-scale ridges with intercalated intra-mountainous basins have probably existed during Mesozoic (Fig. 8a).

Drill wells W1 and W1' (Figs. 4a and 4b) display $\sim 1200 \mathrm{~m}$ of Lower Jurassic sediments (e.g. Badaowan and Shangonghe Fm., Fig. 2). A comparable thickness for Lower Jurassic has also been observed in the Manas area, $50 \mathrm{~km}$ west of the Hutubi section (Fig. 2; Hendrix et al., 1992). Following the geological maps (XBGMR; 1978, 1993), Middle Jurassic series directly lie unconformably onto the Carboniferous basement, without Triassic and Lower Jurassic sediments in the southern part of the Hutubi River (see location A in Fig. 4a). The thickness difference of Jurassic sediments reaches $\sim 1200 \mathrm{~m}$ between the location $\mathrm{A}$ and the drill well location, for a horizontal distance of about $50 \mathrm{~km}$ (Fig. 4a). Such thickness difference may result from subsidence mechanisms. However, whatever the scale considered in this study, Triassic and mostly Jurassic series, up to the late Jurassic Kalaza formation deposit, display parallel bedding with no growth strata observed (Figs. $5 b, 6$ and 7b). Such feature shows that, at the scale of the studied area, significant vertical differential movements may have hardly occurred during Triassic to Upper Jurassic sedimentation. In addition, as 
described above, Jurassic strata often overlie directly on Carboniferous by onlap, without fault or syn-sedimentary deformations. Seismic profiles across the southern margin of the Junggar basin do not display major fault that could have controlled sedimentation for the Early Jurassic period (Allen et al., 1991; Wang et al., 2005). No evidence for structural control on local subsidence could thus be argued here. At larger scale, flexure - either thermal or tectonic - could also have controlled the subsidence for Mesozoic series accumulation.

If considering thermal control, the latest regional tectono-magmatic event occurring before Mesozoic in the Central Tian Shan area ended during early Permian (see compilation by Han et al., 1999), which is about 100 Ma earlier than Jurassic sedimentation. Therefore, according to Hendrix et al. (1992), it seems that thermal driving mechanism may only play a weak role for the Early and Middle Jurassic sedimentation. If considering tectonic control, compressional flexure may also be hard to explain as, for comparable vertical differential movements, buckling of a stable continental lithosphere would result in much larger wavelength $(200-300 \mathrm{~km})$ than observed in this study $(\sim 50 \mathrm{~km})$ as shown by mechanical modelling (Martinod and Davy, 1992, 1994; Burov et al., 1993; Cloetingh et al., 1999).

At the scale of the present study, Jurassic sedimentation seems hardly controlled by either tectonic or thermal subsidence across northern Tian Shan. Accordingly, the 1200$1300 \mathrm{~m}$ thickness difference may be mainly produced by infilling of a long-lasting remnant relief of, at least, 1200-1300 m high at that period (i.e. from Triassic/Lowermost Jurassic; Fig. 8a). During Middle Jurassic, finer-grained sediments were conformably deposited on top of the Lower Jurassic strata within the basin, and were deposited onlap on the Paleozoic basement toward the range (Figs. 5a and 8b). Middle Jurassic sediments of the Xishanyao and Toutunhe formations extend to a larger area with respect to the Lower Jurassic and, as a whole, the paleorelief lateral extension was certainly less important during Middle Jurassic than during Triassic/Early Jurassic (Fig. 8b). During latest Jurassic to Early Cretaceous, thick 
breccias were deposited onto the Middle Jurassic sediments through an angular unconformity (cf. Kalaza Fm.). These breccias are restricted to the front of the modern Tian Shan and change rapidly to finer-grained deposits in lateral equivalents. This configuration is reminiscent of the general architecture of current fans deposited along the modern Tian Shan range that originate from the present day high relief to the south, but show limited northward transport of sediments (Fig. 8c). In turn, location of the main morphological northern front of the paleo- Tian Shan, during Latest Jurassic to Early Cretaceous, would approximately coincide with the one of the current range front (Fig. 5). The uplift documented by these coarse-grained sedimentary breccias is also recorded by AFT chronology studies; Fissiontrack modeling indicates a ca. 160 and 120 Ma cooling age along a Dushanzi-Kuqa corridor, in the mountain interior (Dumitru et al., 2001; Jolivet et al., 2010). Apatite sampled from Bayanbulak area yields the earliest cooling ages of Early Cretaceous (Dumitru et al., 2001; Wang et al. 2009).

Because no major tectonic event occurred in the Northern Tian Shan during Mesozoic times (e.g. De Grave et al., 2007), the Paleozoic subduction-collision orogeny (Gao et al., 1998; Laurent-Charvet et al., 2002; Charvet et al., 2007) appears as the most probable origin of the Mesozoic paleorelief above described. In such case, the Tian Shan would persist as remnant relieves for several tens of $\mathrm{Ma}$ after the end of the orogenic events which are progressively and unconformably overlain by Triassic and then Jurassic sedimentation (e.g. onlap structures, mesoscale paleorelief infilling). This scenario implies extremely low erosion rates to allow the preservation of a significant relief; such feature has already been reported for other regions of Central Asia from thermochronological (AFT) and field data analyses (Jolivet et al., 2007). In parallel, Central Asia Mesozoic tectonic history is marked by the polyphased Cimmerian orogeny in Tibet area (e.g. Hendrix et al., 1992; Sobel and Dumitru, 1997; De Grave et al., 2007). Low amplitude, far-field effects can thus be recognized in the 
Mesozoic northern Tian Shan: one early collision stage - Qiantang/Kunlun blocks during Late

Triassic/Middle Jurassic - would correspond to the drastic coarsening of the Lower Jurassic sedimentation. In turn, a later collision stage - Lhasa/Qiantang blocks during Late Jurassic/Early Cretaceous - well corresponds to the deposits of the thick and coarse breccias of the Kalaza Fm. at that time. In this case, a tectonic origin of the relief rejuvenation is attested by a major angular unconformity observed regionally.

As unambiguously demonstrated, the physiography of the modern Tian Shan dominantly results from the recent tectonic evolution of the area (e.g. Tapponnier and Molnar, 1977; Avouac et al., 1993; Métivier and Gaudemer, 1997; Charreau et al., 2009). However, this study put forward that the current Tian Shan topography can probably not be considered as the consequence of the Cenozoic intracontinental reactivation alone, but as a combination of the Cenozoic deformations superimposed on a reminiscent Mesozoic paleo-range. These new results question on the amplitude of the movements that could be estimated along the northern front structures during Cenozoic intracontinental reactivation.

\section{Acknowledgements}

Field and laboratory work in the present study are financially supported by Chinese National 973 Program (2009CB825008) and Chinese National S\&T Major Project 2011ZX05008.

Prof. A.R. Caroll, Dr. J. Charreau, and an anonymous reviewer are warmly thanked for their constructive reviews. We are also grateful for the help by Prof. Carlo Doglioni (Editor) and Prof. Gerhard Wörner (Associate Editor). Discussions on seismic profiles' interpretation with

Dr. Y. Branquet have also been greatly appreciated. The first author benefices a Ph.D scholarship from French Embassy in Beijing and IGGCAS. 


\section{References}

267

Abdrakhmatov, K.Y., Aldazhanov, S.A., Hager, B.H., Hamburger, M.W., Herring, T.A., Kalabaev, K.B., Makarov, V.I., Molnar, P., Panasyuk, S.V., Prilepin, M.T., Reilinger, R.E., Sadybakasov, I.S., Souter, B.J., Trapeznikov, Y.A., Tsurkov, V.Y. and Zubovich, A.V., 1996. Relatively recent construction of the Tien Shan inferred from GPS measurements of presentday crustal deformation rates. Nature, $\mathbf{3 8 4}, 450-453$.

Allen, M.B., Windley, B.F., Zhang, C., Zhao, Z.Y. and Wang, G.R., 1991. Basin Evolution within and Adjacent to the Tien-Shan Range, NW China. J. Geol. Soc. London, 148, 369-378.

Avouac, J.P., Tapponnier, P., Bai, M., You, H. and Wang, G., 1993. Active Thrusting and Folding Along the Northern Tien-Shan and Late Cenozoic Rotation of the Tarim Relative to Dzungaria and Kazakhstan. J. Geophys. Res., 98, 6755-6804.

Burchfiel, B.C., Brown, E.T., Deng, Q.D., Feng, X.Y., Li, J., Molnar, P., Shi, J.B., Wu, Z.M. and You, H.C., 1999. Crustal shortening on the margins of the Tien Shan, Xinjiang, China. Int. Geol. Rev., 41, 665-700.

Burov, E.B., Lobkovsky, L.I., Cloetingh, S. and Nikishin, A.M., 1993. Continental lithosphere folding in Central Asia (Part II): constraints from gravity and topography. Tectonophysics, 226, 73-87.

Carroll, A.R., Liang, Y., Graham, S.A., Xiao, X., Hendrix, M.S., Chu, J., and McKnight, C.L., 1990. Junggar basin, northwest China: Trapped late Paleozoic ocean. Tectonophysics, 181, 114. 
Carroll, A. R., Graham, S.A., Hendrix, M.S., Ying, D., and Zhou, D., 1995. Late Paleozoic tectonic amalgamation of northwestern China: sedimentary record of the northern Tarim, northwestern Turpan, and southern Junggar basins. Geol. Soc. Am. Bull., 107, 571-594.

Carroll, A.R., Graham, S.A. and Smith, M.E., 2010. Walled sedimentary basins of China. Basin Res., 22, 17-32.

Charreau, J., Chen, Y., Gilder, S., Barrier, L., Dominguez, S., Augier, R., Sen, S., Avouac, J.P., Gallaud, A., Graveleau, F. and Wang, Q.C., 2009. Neogene uplift of the Tian Shan Mountains observed in the magnetic record of the Jingou River section (northwest China). Tectonics, 28, TC2008, doi:10.1029/2007TC002137.

Charvet, J., Shu, L.S. and Laurent-Charvet, S., 2007. Paleozoic structural and geodynamic evolution of eastern Tianshan (NW China): welding of the Tarim and Junggar plates. Episodes, 30, 162-186.

Cloetingh, S., Burov, E. and Poliakov, A., 1999. Lithosphere folding: primary response to compression? (from central Asia to Paris basin). Tectonics, 18, 1064-1083.

De Grave, J., Buslov, M.M. and Van den Haute, P., 2007. Distant effects of India-Eurasia convergence and Mesozoic intracontinental deformation in Central Asia: Constraints from apatite fission-track thermochronology. J. Asian Earth Sc., 29, 188-204.

Deng, Q.D., Zhang, P.Z., Xu, X.W., Yang, X.P., Peng, S.Z., and Feng, X.Y., 1996. Paleoseismology of the northern piedmont of Tianshan Mountains, northwestern China. $J$. Geophys. Res., 101, 5895-5920.

Dumitru, T.A., Zhou, D., Chang, E.Z., Graham, S.A., Hendrix, M.S., Sobel, E.R., and Caroll, A.R., 2001. Uplift, exhumation, and deformation in the Chinese Tian Shan. in: Paleozoic and 
Mesozoic tectonic evolution of central Asia: From continental assembly to intracontinental deformation (Hendrix, M.S., and Davis,G.A., eds). Geol. Soc. Am. Mem., 194, 71-99.

Gao, J., Li, M.S., Xiao, X.C., Tang, Y.Q. and He, G.Q., 1998. Paleozoic tectonic evolution of the Tianshan Orogen, northwestern China. Tectonophysics, 287, 213-231.

Graham, S.A., Hendrix, M.S., Wang, L.B. and Carroll, A.R., 1993. Collisional successor basins of western China Impact of tectonic inheritance on sand composition. Geol. Soc. Am. Bull., 105, 323-344.

Han B.F., He, G.Q. and Wang, S., 1999. Postcollisional mantle-derived magmatism, underplating and implications for basement of the Junggar Basin. Sci. China. Ser. D, 42, 113119.

Hendrix, M.S., Graham, S.A., Carroll, A.R., Sobel, E.R., Mcknight, C.L., Schulein, B.J., and Wang, Z.X., 1992. Sedimentary Record and Climatic Implications of Recurrent Deformation in the Tian-Shan - Evidence from Mesozoic Strata of the North Tarim, South Junggar, and Turpan Basins, Northwest China. Geol. Soc. Am. Bull., 104, 53-79.

Hendrix, M.S., Dumitru, T.A. and Graham, S.A., 1994. Late Oligocene Early Miocene Unroofing in the Chinese Tien-Shan - an Early Effect of the India-Asia Collision. Geology, 22, 487-490.

Hendrix, M.S., 2000. Evolution of mesozoic sandstone compositions, southern Junggar, northern Tarim, and western Turpan basins, northwest China: A detrital record of the ancestral Tian Shan. J. Sed. Res., 70, 520-532.

Huang, B. and Li, J., 2007. Sporopollen assemblages from the Xishanyao and Toutunhe formations at the Honggou section of the manasi river, xinjiang and their stratigraphical significance. Acta Micropaleontologica Sinica, 24, 170-193. 
331 Jolivet, M., Ritz, J.F., Vassalo, R., Larroque, C., Braucher, R., Todbileg, M., Chauvet, A., Sue,

332 C., Arnaud, N., de Vicente, R., Arzhanikova, A. and Arzhanikova, S., 2007. Mongolian 333 summits: An uplifted, flat, old but still preserved erosion surface. Geology, 35, 871-874.

334 Jolivet, M., Dominguez J., Charreau J., Chen, Y., Farley, K.A., Li, Y.A. and Wang, Q.C., 335 2010. Mesozoic and Cenozoic tectonic history of the Central Chinese Tian Shan: Reactivated 336 tectonic structures and active deformation. Tectonics, 29, TC6019, 337 doi:10.1029/2010TC002712.

338 Laurent-Charvet S., Charvet, J., Shu, L.S., Ma, R.S. and Lu, H.F., 2002. Late Paleozoic 339 collisional strike-slip deformations in Tianshan and Altay, eastern Xinjiang, NW China. Terra $340 \quad$ Nova, 14, 249-256.

341 Li Z., Zhang L., Qian C., Wang Y. and Bai G., 1978. Regional geological survey report of 342 Geological map 1:200000, Shichang sheet. China Ministry of Geology and Mineral Resource, 343 Beijing.

Li, Z., Song, W.J., Peng, S.T., Wang, D.X. and Zhang, Z.P., 2004. Mesozoic-Cenozoic 345 tectonic relationships between the Kuqa subbasin and Tian Shan, northwest China: constraints 346 from depositional records. Sed. Geol., 172, 223-249.

Liu, Z., 1990. Sporo-pollen assemblage from Middle Jurassic Xishanyao Formation of 348 Shawan, Xinjiang, China. Acta Palaeontologica Sinica, 29, 63-82. Margin of the Junggar Basin, Xinjiang and the T-J Boundary. Acta Geologica Sinica, 79, 1528. 
352 Martinod, J., and Davy, P., 1992. Periodic instabilities during compression of the lithosphere

353 1. Deformation modes from an analytical perturbation method. J. Geophys. Res., 92, 19993542014.

355 Martinod, J. and Davy, P., 1994. Periodic instabilities during compression of the lithosphere 2. 356 Analogue experiments. J. Geophys. Res., 99, 12057-12069.

357 Métivier, F. and Gaudemer, Y., 1997. Mass transfer between eastern Tien Shan and adjacent 358 basins (central Asia): Constraints on regional tectonics and topography. Geophys. J. Int., 128, $359 \quad 1-17$.

Sengör, A.M.C., Natal'in, B.A., Burtman, V.S., 1993. Evolution of the Altaid tectonic collage and Paleozoic crust growth in Eurasia. Nature, 364, 299-307.

Sobel, E.R. and Dumitru, T.A., 1997. Thrusting and exhumation around the margins of the western Tarim basin during the India-Asia collision. J. Geophys. Res., 102, 5043-5063.

Tapponnier, P. and Molnar, P., 1977. Active Faulting and Tectonics in China. J. Geophys. Res., 82, 2905-2930.

Wang, B. Chen, Y., Zhan, S., Shu, L.S., Faure, M., Cluzel, D., Charvet, J. and LaurentCharvet, S., 2007. Primary Carboniferous and Permian paleomagnetic results from the Yili Block (NW China) and their implications on the geodynamic evolution of Chinese Tian Shan Belt. Earth Planet. Sci. Lett., 263, 288-308.

Wang, Q. C., Li S. J. and Du z. L., 2009. Differential uplift of the Chinese Tian Shan since the Cretaceous: constraints from sedimentary petrography and apatite fission-track dating. Int. J. Earth Sci., 98, 1341-1363. 
373 Wang, X.W., Wang, X.W., Liu, J.P., Liu, J.P. and Ma, Y.S., 2005. Analysis of the fold-thrust 374 zone in the southern Junggar Basin, north western China. Earth Science Frontiers, 12, 411375421.

376 Wang, Z., Wu, J., Lu, X., Liu, C., and Zhang, J., 1990, Polycyclic tectonic evolution and 377 metallogeny of the Tian Shan mountains. Beijing, Science Press.

378 Windley, B.F., Allen, M.B., Zhang, C., Zhang, C., Zhao, Z.Y. and Wang, G.R., 1990.

379 Paleozoic accretion and Cenozoic redeformation of the Chinese Tien Shan range, Central Asia. 380 Geology, 18, 128-131.

XBGMR-WUSU, 1973, Bureau of Geological and Mineral Resources of Xinjiang Uygur 382 Autonomous Region, Geological map of Wusu Region, Scale 1:200.000, China Ministry of Geology and Mineral Resource, Beijing.

XBGMR-HOUXIA, 1977, Bureau of Geological and Mineral Resources of Xinjiang Uygur Autonomous Region, Geological map of Houxia Region, Scale 1:200.000, China Ministry of Geology and Mineral Resource, Beijing.

XBGMR-SHICHANG, 1978, Bureau of Geological and Mineral Resources of Xinjiang Ministry of Geology and Mineral Resource, Beijing.

XBGMR, 1993, Regional geology of Xinjiang Uygur autonomy region.- Geological Memoirs, 379. 
395 Yang, J.L, Wang Q.F. and Lu H.N., 2005, Discovery of cretaceous and Paleocene charophyte 396 floras from well $\mathrm{Hu}-2$ in the southern edge of Junggar basin. Acta Micropalaeontologica 397 Sinica, 22, 251-268. 


\section{Figure captions}

399

400

401

402

403

404

405

406

407

408

409

410

411

412

413

414

415

416

417

418

419

420

Fig. 1 Simplified geological map of the northern Tian Shan from Wusu to Urumqi areas.

Mesozoic is most exposed in the southernmost parts of the Junggar basin along the adjacent

Tian Shan range, particularly to the East (Urumqi area). 'He' indicates river in Chinese (modified after XBGMR, 1993).

Fig. 2 Synthetic and representative stratigraphic log made in the Manasi He area, northern Tian Shan piedmont, where Cenozoic have been widely eroded (modified after Hendrix et al., 1992).

Fig. 3 Landscape pictures of representative features of the Mesozoic sedimentary series (see locations on Fig.1) (a) Coarse-grained conglomerate of lowermost Jurassic forming prominent bars in the landscape (southern Qingshui He area); (b) Uppermost Jurassic coarse-grained breccias (Kalaza Fm. - $\left.\mathbf{J}_{3 \mathrm{k}}\right)$ unconformably overlying the Upper Jurassic Qigu formation $\left(\mathrm{J}_{3 q}\right.$; Hutubi He area); (c) Close-up view of the Uppermost Jurassic Kalaza Fm. breccias (west to Hutubi He area). Note the angular shape of the clasts (locally exceeding $50 \mathrm{~cm}$ ) and the clastsupported character of the coarser levels.

Fig. 4 Structural and sedimentological observations in the Houxia area. (a) Simplified geological map with some field structural measurements (modified after XBGMR, 1977), (b) detailed geological cross-section across the northern limb of the syncline structure (see location on Fig. 4a), (c) Close-up view of the Lower Jurassic breccias including Carboniferous basement angular clasts (see location on Fig. 4b), (d) picture of the steep bedding of Jurassic layers close to the southward thrust (see location on Fig. 4b).

Fig. 5 (a) Simplified geological map of the Hutubi He area (modified after XBGMR, 1978, 1993) with few structural measurements from field work. 'A' indicates location where Middle 
Jurassic deposits directly and unconformity lie onto Carboniferous basement without Triassic or Lower Jurassic, (b) Geological cross-section along the Hutubi He constrained by field data, seismic profile (after Wang et al., 2005) and nearby drill wells W1 and W1'. Location of the section is indicated on Fig. 5a. Extension of the available seismic profile is indicated on the section.

Fig. 6 Examples of onlap structures of the Jurassic sediments over the Paleozoic basement units. (a) Picture and interpretation field sketch of the southern part of the Hutubi He (see location on Fig. 5a): note the overall southward onlap of the Jurassic sediments over the folded basement. To the north, a basement block is back thrusted over the sediments (see Fig. 5b), (b) Picture and interpretation field sketch of a small valley, west of the Hutubi $\mathrm{He}$ (see location on Fig. 5a): meso-scale basement relief covered by Jurassic sandstones as evidenced by onlaps over a steep inherited $\sim 150 \mathrm{~m}$ high basement paleorelief (scarp). Basement rocks are deformed with a large inclined Paleozoic fold.

Fig. 7 Structural and sedimentological observations in the Wusu area. (a) Simplified geological map (modified after XBGMR, 1973) with few structural measurements. (b) Geological cross-section constrained by field data, seismic profile and drill well W2 (see Fig. 7a for location). (c) Picture and corresponding field sketch interpretation of the unconformable contact between Jurassic layers and the Carboniferous basement (see Fig. 7a for location).

Fig. 8 Sketch views of the paleogeographic evolution of the northern piedmont of Tian Shan during Early, Middle and Upper Jurassic/Cretaceous boundary. Main observations that constrain this study are localized on the drawings as: A for Fig. 3a; B for Fig. 4c (lower Jurassic sedimentary breccias); C for Fig. 6a (onlap covering of Paleozoic basement rocks by 
444 Jurassic sandstones) and D for Figs. 3b and 3c (thick Kalaza Fm. breccias with angular 445 discordance at the base). 